$1-1-2011$

\title{
Substance, Procedure, and the Divided Patent Power
}

Joseph S. Miller

University of Georgia School of Law, getmejoe@uga.edu

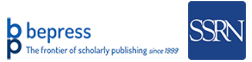

\section{Repository Citation}

Joseph S. Miller, Substance, Procedure, and the Divided Patent Power, 63 Admin. L. Rev. 31 (2011), Available at: https://digitalcommons.law.uga.edu/fac_artchop/974

This Article is brought to you for free and open access by the Faculty Scholarship at Digital Commons @ University of Georgia School of Law. It has been accepted for inclusion in Scholarly Works by an authorized administrator of Digital Commons @ University of Georgia School of Law. Please share how you have benefited from this access For more information, please contact tstriepe@uga.edu. 


\title{
SUBSTANCE, PROCEDURE, AND THE DIVIDED PATENT POWER
}

\author{
JOSEPH SCOTT MILLER*
}

TABLE OF CONTENTS

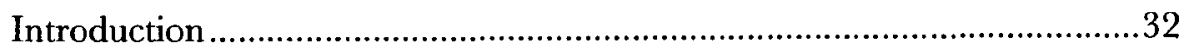

I. Splitting the Patent Power ............................................................39

II. Fitting the Best Model.....................................................................46

III. Quitting the Bad Models ...............................................................62

A. The Patent Act's Reliance on Notice-and-Comment

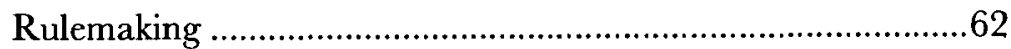

B. The APA's Substance-Procedure Distinction ............................65

C. The Rules of Decision Act's Substance-Procedure

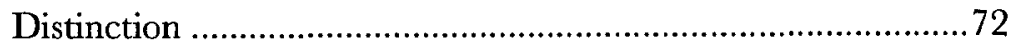

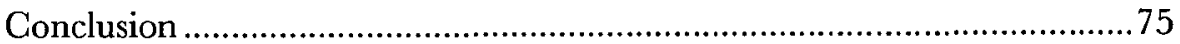

* Professor, Lewis \& Clark Law School. Participants at the George Washington University Law School's Fall 2009 IP Workshop Series offered insightful, challenging comments that helped me improve the piece. Lydia Loren and Jan Neuman highlighted weak spots in an early version that helped me focus my efforts. Bill Funk, Tom Merrill, and Jim Speta helped with administrative law, and Ed Brunet and Juliet Stumpf helped with civil procedure. Connie Trela gave a welcome critical read. 
The answer to the question, "What is procedure?" depends upon the answer to another question, "Why do you want to know?"I

The line between "substance" and "procedure" shifts as the legal context changes. ${ }^{2}$

\section{INTRODUCTION}

In 1790 , Congress split its patent power. ${ }^{3}$ Rather than grant patents itself by private bill, Congress enacted a general patent law, ${ }^{4}$ creating a patent board in the Executive Branch with the delegated power to grant patents according to statutorily prescribed standards. ${ }^{5}$ The Patent Office (the Office) we know today, created in the 1836 Patent Act, ${ }^{6}$ received its broadest grant of regulatory power from Congress in $1870 . .^{7}$ The terms of the grant remain the same today: "The Office... may establish regulations, not inconsistent with law, which . . . shall govern the conduct of proceedings in the Office . . ."8 Just how broad is this grant?

It is settled that Congress has given the Patent Office the power to issue procedural rules for patent examination at the Office, not substantive

1. Thomas Fitzgerald Green, Jr., To What Extent May Courts Under the Rule-Making Power Prescribe Rules of Evidence?, 26 A.B.A. J. 482, 483 (1940).

2. Hanna v. Plumer, 380 U.S. 460, 471 (1965) (differentiating the substanceprocedure distinction used in applying the Erie doctrine from the substance-procedure distinction used to test the validity of a Federal Rule of Civil Procedure under the Rules Enabling Act).

3. U.S. ConsT. art. I, $\S 8$, cl. 8 ("The Congress shall have Power ... To promote the Progress of Science and useful Arts, by securing for limited Times to Authors and Inventors the exclusive Right to their respective Writings and Discoveries.").

4. Act of Apr. 10, 1790, ch. 7, 1 Stat. 109.

5. See generally P.J. Federico, Operation of the Patent Act of 1790, 18 J. PAT. OFF. SOC'Y 237 (1936).

6. Act of July 4, 1836, ch. 357, 5 Stat. 117; see also EdWARd C. WaLTerscheid, To PRomote the Progress OF USEFUl ARTS: AMERICAN PATENT LAW AND ADMINISTRATION, 1798-1836, at 1 (1998).

7. Act of July 8, 1870, ch. 230, §19, 16 Stat. 198, 200 ("And be it further enacted, That the commissioner, subject to the approval of the Secretary of the Interior, may from time to time establish rules and regulations, not inconsistent with law, for the conduct of proceedings in the patent office.").

8. 35 U.S.C. $\S 2$ (b)(2)(A) (2006). Before 1999, the provision was found at 35 U.S.C. $\S 6$ (a) (1994). The scope of the grant on the Patent and Trademark Office's (the Office's) trademark side is the same. See 15 U.S.C. $\$ 1123$ (2006) ("The Director shall make rules and regulations, not inconsistent with law, for the conduct of proceedings in the Patent and Trademark Office under this chapter."). The language dates from the 1905 federal trademark registration act, Act of Feb. 20, 1905, ch. 592, § 26, 33 Stat. 724, 730, and was preserved in the Lanham Act of 1946, ch. 540, $\$ 41,60$ Stat. 427, 440 (codified as amended in scattered sections of 15 U.S.C. (2006)). 
rulemaking power of the sort federal agencies typically possess. ${ }^{9}$ But people differ sharply over how-or where-to draw the line the Patent Act demands between proper procedural rules and improper substantive rules. When the Office asserts that a given rule is procedural and an applicant blocked from patent rights by the rule contends that it is substantive, the need for a means to distinguish procedural from substantive rules is plain.

The scope of the Patent Office's procedural power is a pressing question, as recent events illustrate. The Office groans beneath the weight of a substantial backlog of applications, built up as the utility patent ${ }^{10}$ application filing rate doubled between 1998 and 2008. ${ }^{11}$ Simply

9. Merck \& Co. v. Kessler, 80 F.3d 1543, 1549-50 (Fed. Cir. 1996) (denying Chevron deference to a Patent Office construction of a patent term extension statute on the ground that "Congress has not vested the Commissioner with any general substantive rulemaking power"); Animal Legal Def. Fund v. Quigg, 932 F.2d 920, 930 (Fed. Cir. 1991) ("[T] authority granted in section 6 [now $\S 2$ ] is directed to the 'conduct of proceedings' before the Office. A substantive declaration with regard to the Commissioner's interpretation of the patent statutes, whether it be section 101, 102, 103, 112 or other section, does not fall within the usual interpretation of such statutory language."). One may well question whether, as an original matter, Merck and Quigg provide the sounder construction of $\S 2(\mathrm{~b})(2)(\mathrm{A})$. Patent Office "proceedings" are, chiefly, examinations for patentability under the Patent Act's substantive standards. See 35 U.S.C. § 131. The "conduct of [these] proceedings" could fairly be thought - at least as a textual matter - to entail Patent Office resolution of any ambiguities in the Patent Act's substantive patentability standards. Congress, however, reenacted this grant of regulatory power in 1999, post-Merck, both moving the provision to a different part of the Patent Act and modifying some of its terms. See Patent and Trademark Office Efficiency Act, Pub. L. No. 106-1 13, 113 Stat. 1501A-572, 1501A-572 to 1501A-573 (1999) (Title IV, Subtitle G, $\$ 4712$ of the Intellectual Property and Communications Omnibus Reform Act of 1999, included as Appendix I to an appropriations bill). According to the Supreme Court's statutory construction jurisprudence, Congress has thereby ratified Merck's "procedure, not substance" construction of § 2(b)(2)(A). See Barnhart v. Walton, 535 U.S. 212, 220 (2002); Cottage Sav. Ass'n v. Comm'r, 499 U.S. 554, 561 (1991) (quoting Helvering v. Winmill, 305 U.S. 79, 83 (1938)); CFTC v. Schor, 478 U.S. 833, 846 (1986) (quoting NLRB v. Bell Aerospace Co., 416 U.S. 267, 275 (1974)).

10. U.S. law provides for three types of patents: utility patents, design patents, and plant patents. Utility patents cover useful, new, and nonobvious products and processes. 35 U.S.C. $\S \S 101-103$. This is the sort of patent most people think of as, simply, a patent. Design patents cover new, original, and ornamental designs for "article[s] of manufacture." 35 U.S.C. \$§171-173. Plant patents cover distinct and new varieties of asexually reproduced plants. 35 U.S.C. $\S \S 161-164$. The Patent Office grants many more utility patents than design or plant patents. For example, during the ten years from 1999 to 2008 inclusive, the Patent Office granted 1,610,289 utility patents (or about 161,000 per year); 180,279 design patents (or about 18,000 per year); and 8,847 plant patents (or about 885 per year). See U.S. Patent \& Trademark Office, U.S. Patent Statistics, Calendar YEARS 1963-2009 (Apr. 2010), http://www.uspto.gov/web/offices/ac/ido/oeip/ taf/us_stat.pdf(reporting annual application and grant totals).

11. Arti K. Rai, Growing Pains in the Administrative State: The Patent Office's Troubled Quest for Managerial Control, 157 U. PA. L. REV. 2051, 2057-60 (2008) (discussing the Patent Office's 
continuing to work as it has in the past is surely not a sustainable strategy. A package of purportedly ameliorative rules that the Office first announced in January 2006, and finalized in August 2007, ${ }^{12}$ never went into effect. The rules, which struck many patent applicants as too harshly constricting, ${ }^{13}$ stalled in litigation over whether they were substantive and thus invalid. The trial court, in what is known as the Tafas I case, concluded that all these new rules were substantive and thus enjoined them. ${ }^{14}$ The Federal Circuit, in the Office's appeal in Tafas II, concluded that the rules were procedural in a split panel opinion in March 2009.15 In July 2009, the full Federal Circuit granted en banc review in Tafas $I I I$ of the question and vacated the panel opinion. ${ }^{16}$ In October 2009, the Office announced that it was rescinding the proposed rules ${ }^{17}$ and settling the litigation. ${ }^{18}$ The fitting scope of the Office's regulatory authority-the issue at the heart of the Tafas cases-thus remains in doubt. The agency problems that inspired the rules continue. New rules, likely to trigger strong objections from at least some of the patent system's repeat players,

"Increased Workload and Backlog").

12. Changes to Practice for Continue Examination Filings, Patent Applications Containing Patentably Indistinct Claims, and Examination of Claims in Patent Applications, 72 Fed. Reg. 46,716 (Aug. 21, 2007).

13. See id. at $46,716-17$ (reporting objections received during the public comment period on the draft regulations). The rules purportedly sought to streamline the process whereby applicants press their claims to utility patent protection over time. Specifically, the rules, if implemented, would have limited the availability of continuation applications and requests for continued examination (Final Rules 78 and 114), and-for applications containing either more than five independent claims or more than twenty-five total claimswould have required an applicant to submit a new "examination support document," or ESD, explaining the prior art information presented to the Office (Final Rules 75 and 265). Id. The reader interested in more detailed discussion of the rules, which is beyond the scope of this article, should consult Kali Murray, First Things, First: A Principled Approach to Patent Administrative Law, 42 J. MARSHALL L. Rev. 29, 30-32 (2008).

14. Tafas v. Dudas (Tafas I), 541 F. Supp. 2d 805 (E.D. Va. 2008), affd sub nom. Tafas v. Doll (Tafas II), 559 F.3d 1345 (Fed. Cir. 2009), vacated en banc, Tafas v. Doll (Tafas III) 328 Fed. App'x 658 (Fed. Cir. 2009) (appeal reinstated). Although the plaintiffs in the case-Mr. Tafas and Smithkline Beecham Corp.- raised several attacks on the rules, the district court adjudicated only one: " $[T]$ he Court finds that the Final Rules are substantive in nature and exceed the scope of the USPTO's rulemaking authority under 35 U.S.C. § 2(b)(2)." Id. at 811.

15. Tafas $I I, 559$ F.3d 1345.

16. Tafas III, 328 Fed. App'x 658.

17. Changes to Practice for Continued Examination Filings, Patent Applications Containing Patentably Indistinct Claims, and Examination of Claims in Patent Applications, 74 Fed. Reg. 52,686 (Oct. 14, 2009).

18. Press Release, U.S. Patent \& Trademark Office, USPTO Rescinds Controversial Patent Regulations Package Proposed by Previous Administration (Oct. 8, 2009), available at http://www.uspto.gov/news/09_21.jsp. 
seem inevitable. ${ }^{19}$

Thus far, the courts have failed to provide a robust standard for sorting proposed Patent Office rules into procedure and substance boxes, parsing the valid from the invalid. Perhaps this should be expected. Procedure and substance are protean concepts; they "carry no monolithic meaning at once appropriate to all the contexts in which courts have seen fit to employ them."20 Indeed, courts sort the two from one another with different standards, depending on the reason for sorting them in a given case. Although it is tough to frame a stable sorting standard for the Patent Office context, it can and should be done. ${ }^{21}$ The alternative--fitful ad hoceryfrustrates planning and wastes resources. Thus, the Federal Circuit should put the scope of the Patent Office's procedural power on firm ground, for the sake of the Office and patent applicants alike.

The courts have flirted with a range of power-defining options for the patent law context, most notably the substance-procedure distinction in notice-and-comment rulemaking conducted under $\S 553$ of the Administrative Procedure Act (APA). ${ }^{22}$ This APA framework, however, is actually quite ill-suited for the Patent Office. This framework is designed to protect public participation in rulemaking proceedings conducted by agencies that-unlike the Patent Office-have the power to make substantive rules with the force of law (if they use notice-and-comment) but can dispense with notice-and-comment for "rules of agency organization, procedure, or practice." 23 Such agencies may be tempted to save time and

19. The press release about the Tafas case settlement speaks in these terms. According to Director Kappos, "[t]his course of action represents the most efficient way to formally and permanently move on from these regulations and work with the IP community on new ways to take on the challenges these regulations were originally designed to address." Id. (emphases added).

20. John Hart Ely, The Irrepressible Myth of Erie, 87 HARV. L. REV. 693, 724 (1974).

21. See Stephen B. Burbank, The Rules Enabling Act of 1934, 130 U. PA. L. REv. 1015, 1105 n.413 (1982) ("But the logical and practical difficulties of classifying a matter as procedure or substance are not sufficient reason to abandon the enterprise, at least when it is required by statute.").

22. 5 U.S.C. $§ 553(\mathrm{~b})$ (2006). In the Tafas litigation, both the district court and the Federal Circuit discussed the Administrative Procedure Act's (APA's) substance-procedure distinction. The Federal Circuit, however, was careful to state that it " $\mathrm{d}[\mathrm{id}]$ not purport to set forth a definitive rule for distinguishing between substance and procedure in" that, or any, case. Tafas II, 559 F.3d 1345, 1356 (Fed. Cir. 2009), vacated en banc, Tafas III, 328 Fed. App'x 658 (Fed. Cir. 2009) (appeal reinstated).

23. 5 U.S.C. $§ 553(\mathrm{~b})$, I 2(A). See U.S. DeP'T of Justice, Attorney General's Manual on the Administrative Procedure ACT 26 (1947) ("In general, the purpose of section 4 [now codified at 5 U.S.C. $\$ 553$ ] is to guarantee to the public an opportunity to participate in the rule making process. With stated exceptions, each agency will be required under this section to give public notice of substantive rules which it proposes to adopt, and to grant interested persons an opportunity to present their views to it."); see also id. at 9 (listing, 
expense by miscategorizing a substantive rule as procedural. ${ }^{24}$ When a court later analyzes whether a challenged rule from such an agency is substantive or procedural, what is really at stake is how not whether-the agency can establish the substantive rule it wants. By contrast, the Patent Office question of interest here is precisely whether the Office can issue a rule because it is procedural.

This Article identifies a stable standard for sorting procedural from substantive rules that better fits the way Congress has split responsibility for granting patents between itself and the Patent Office. The allocation is straightforward: Under the general-purpose patent regime it established in 1836, and that continues today, Congress sets detailed substantive policy in the Patent Act to govern the patentability of all patent applications, and the Patent Office examines individual applications for Patent Act compliance in proceedings for which it has established procedures by rule. ${ }^{25}$ What sorting standard fits this allocation of responsibility? The key is to recognize that the way that Congress has split its patent power echoes strongly in the

among the APA's "four basic purposes," the purpose "[t]o provide for public participation in the rule making process"). "The Attomey General's Manual . . . remains the principal guide to the structure and intent of the APA." ABA SECTION OF ADMIN. LAW \& REGULATORY Practice, Am. Bar Ass'n, Federal administrative Procedure Sourcebook 2 (William F. Funk, Jeffrey S. Lubbers \& Charles Pou, Jr. eds., 4th ed. 2008).

24. If an agency wants to defend its abbreviated process for generating a challenged rule on the ground that the rule is merely procedural, the reviewing court's task isunderstandably - to beware an agency attempt to cut this rulemaking corner and thereby cut the public out of its commenting role. As the D.C. Circuit has put it, " $t]$ he issue ... "is one of degree,' and our task is to identify which substantive effects are 'sufficiently grave so that notice and comment are needed to safeguard the policies underlying the APA." JEM Broad. Co. v. FCC (7EM), 22 F.3d 320, 327 (D.C. Cir. 1994) (quoting Lamoille Valley R.R. v. Interstate Commerce Commission, 711 F.2d 295, 328 (D.C. Cir. 1983)). On protecting public participation, see 1 Richard J. Pierce, Jr., Administrative LaW Treatise $\S 6.5$, at 351 (4th ed. 2002); on agency temptation to cut corners by misdesignating a substantive rule as "procedural," see WiLliam F. FunK \& Richard H. SEAmON, ADMINISTRATIVE LaW: EXAMPLES AND EXPLANATIONS 157 (3d ed. 2009).

25. Professor Kerr has described the Patent Office as Congress's contracting agent, urging that " $[t]$ he patent system operates not through regulation, but rather through the private law mechanisms of contract, property, and tort." Orin S. Kerr, Rethinking Patent Law in the Administrative State, 42 WM. \& MARY L. REV. 127, 129 (2000). According to Kerr,

[a]lthough Congress generates the offer that the patent laws represent, it cannot itself review the hundreds of thousands of applications filed every year in response to the offer. Instead, Congress created the PTO to serve as its agent. The PTO analyzes the submitted claims on Congress's behalf and determines which applicants have accepted Congress's offer.

Id. at 138 (footnote omitted); see also id. at 140 ("As an agent hired by Congress, the PTO acts as an offeror who must determine whether an offeree has triggered a legal obligation by accepting his offer.'). Kerr's contract analogy captures the Office's role. 
pattern Congress later set for federal law generally in 1934, in the Rules Enabling Act. ${ }^{26}$ Under the Rules Enabling Act framework, Congress sets detailed substantive policy governing national law in the United States Code, and the federal judiciary adjudicates disputes under law in proceedings for which it has established procedures by rule (such as those embodied in the Federal Rules of Civil Procedure and related rules). ${ }^{27}$ Following this echo back to its source, the courts should, mutatis mutandis, hold the Patent Office to the same procedural domain under the Patent Act to which they hold themselves under the Rules Enabling Act. Specifically, a Patent Office rule that incidentally affects applicants' substantive rights does not violate $\S 2(\mathrm{~b})(2)$ (A) of the Patent Act if the rule is reasonably necessary to establish or preserve the fair and effective patent examination process that the Office's rules must organize. ${ }^{28}$

This Article proceeds in three parts. Part I takes up two preliminary matters. First, Congress has created the necessity for Patent Office procedural rules by splitting the patent power's substantive and procedural parts between the Legislative and Executive Branches. Had Congress exercised the patent power entirely by itself, in the unified form in which the Constitution confers it, matters of patent-petition procedure might have

26. Act of June 19, 1934, ch. 651, 48 Stat. 1064. The Rules Enabling Act is now codified, in relevant part, at 28 U.S.C. $\$ 2072(a)-(b)(2006)$ :

(a) The Supreme Court shall have the power to prescribe general rules of practice and procedure and rules of evidence for cases in the United States district courts (including proceedings before magistrate judges thereof) and courts of appeals.

(b) Such rules shall not abridge, enlarge or modify any substantive right. All laws in conflict with such rules shall be of no further force or effect after such rules have taken effect.

27. The Judicial Conference's Committee on Rules of Practice and Procedure coordinates the judiciary's rulemaking process. 28 U.S.C. $\S 2073$ (2006). The Administrative Office of the U.S. Courts maintains a helpful set of informal resources on the rulemaking process at http://www.uscourts.gov/RulesAndPolicies.aspx. For a formal description, with citations, see Daniel R. Coquillette, Scope and Purpose, in 1 MOORE's Federal Practice $\S 1.04[3][\mathrm{b}]$, at 1-19 to 1-20 (3d ed. 2009).

Professor Kerr has, in a similar vein, compared the Office's regulatory grant to a trial court's inherent power to manage its cases. See Kerr, supra note 25, at 166-67 ("Congress delegated to the PTO a narrowly circumscribed regulatory authority to manage PTO proceedings, roughly analogous to the power that a federal district court may exercise over the management of its own cases. Pursuant to this explicit grant of regulatory power, the PTO Commissioner has promulgated over 300 pages of regulations.... The Federal Circuit has properly applied deferential standards of review (including Chevron) to such rules, much like appellate courts afford deferential standards of review to district court trialmanagement decisions." (footnotes omitted)).

28. Cf. Burlington N. R.R. v. Woods, 480 U.S. 1, 5 (1987) ("Rules which incidentally affect litigants' substantive rights do not violate this provision if reasonably necessary to maintain the integrity of that system of rules."). 
remained less differentiated from matters of patent-policy substance than they are today. However, having delegated patent application review to the Office, under a Patent Act text that is much longer on patentability substance than it is on examination procedure, Congress made Officepromulgated procedural rules inevitable. Second, it is a truism that procedural choices affect substantive results. As a consequence, courts cannot test the validity of Patent Office rules simply according to whether they affect substantive results. To do so would collapse the very separation of procedure from substance that Congress established in the Patent Act. Thus, "affects substance" is the one sorting standard that we know to a certainty is incorrect.

Part II explores the Rules Enabling Act model. This model yields a solid standard for sorting the Patent Office's procedural sheep from substantive goats. This Part also draws on court oversight of Equal Employment Opportunity Commission (EEOG) administration of Title VII of the Civil Rights Act of $1964,{ }^{29}$ administration that-like Patent Office administration - is limited to the promulgation of procedural rules. ${ }^{30}$ Part III shows the unsuitability of two other approaches for distinguishing procedure from substance- one from the APA context (where ensuring public participation dominates), and the other from the Rules of Decision $\mathrm{Act}^{31}$ context (where preventing forum shopping dominates).

29. 42 U.S.C. $\$ \S 2000 \mathrm{e}-1$ to $2000 \mathrm{e}-17(2006)$.

30. See 42 U.S.C. $§ 2000 \mathrm{e}-12$ (a) ("The Commission shall have authority from time to time to issue, amend, or rescind suitable procedural regulations to carry out the provisions of this subchapter."); Rebecca Hanner White, The EEOC, the Courts, and Employment Discrimination Policy: Recognizing the Agency's Leading Role in Statutory Interpretation, 1995 UTAH L. REv. 51, 56 (observing that "Title VII ... expressly delegated to the agency only the power to issue procedural rules" and that the Supreme Court "has interpreted Title VII as denying the EEOC the power to engage in substantive legislative rulemaking").

31. 28 U.S.C. $\S 1652$ (2006) ("The laws of the several states, except where the Constitution or treaties of the United States or Acts of Congress otherwise require or provide, shall be regarded as rules of decision in civil actions in the courts of the United States, in cases where they apply."). 


\section{SPLiTTING THE PATENT POWER}

The Progress Clause ${ }^{32}$ empowers Congress to grant patents to inventors either directly by private bills, or indirectly by establishing an administrative system; both approaches "secur[e]" to inventors their exclusive rights. Inventors immediately began to petition the first Congress for private patent bills, ${ }^{33}$ consistent with the historical practice whereby state-and, earlier, colonial-legislatures had granted utility patents by private bills. ${ }^{34}$ "As far as the petitioners were concerned, the only effect of the constitutional clause was to transfer the familiar grant practice to the federal level." 35

These petitions forced Congress to confront a basic question of patent system design: "Would it seek to enact individual private laws granting exclusive patent rights as the states had done, or would it instead enact a generic law under the authority of the [Progress Clause]?"36 As Congress began to work out an answer, it referred the first utility patent petition,

32. U.S. ConsT. art. I, $\S 8, \mathrm{cl} .8$ (empowering Congress "[t]o promote the Progress of Science and useful Arts, by securing for limited Times to Authors and Inventors the exclusive Right to their respective Writings and Discoveries"). Naming this clause presents a value choice. Some call it the Copyright and Patent Clause, though neither of those terms appears in it. Others call it the Intellectual Property Clause, though, again, the phrase is absent, and the word "property," which is used in the Constitution (but not here), abounds with connotation. Still others call it the Exclusive Rights Clause, which at least has the virtue of a textual ground; but that name highlights the legal tool it gives Congress to use, rather than the social goal it empowers Congress to pursue. I call it the Progress Clause.

33. "The First Congress, having opened on March 4, 1789, was only a little more than a month old when it first received two petitions relating to intellectual property." BRUCE W. Bugbee, Genesis of American Patent and Copyright LaW 131 (1967). Petitioner John Churchman "claimed that he had invented certain methods of navigation by means of magnetic variation," and "[h]e asked for the passage of a law vesting in him the exclusive right to sell in the United States all globes, maps, and tables constructed according to the principles which he had devised." Id. at 132 . Several more petitions for private patent bills followed. Id. at 133-36; see also WALTERSCHEID, supra note 6, at 81-87 (discussing congressional receipt and consideration of these early petitions).

34. See generally P.J. Federico, Colonial Monopolies and Patents, 11 J. PAT. OFF. Soc'Y 358 (1929); P.J. Federico, State Patents, 13 J. PAT. OFF. Soc'Y 166 (1931). Bugbee also discusses colonial and state patents at length. See BUGBEE, supra note 33, at 57-68 (discussing colonial patents), 84-103 (discussing state patents).

35. Oren Bracha, The Commodification of Patents 1600-1836: How Patents Became Rights and Why We Should Care, 38 Loy. L.A. L. Rev. 177, 217 (2004); see also Frank D. Prager, Historic Background and Foundation of American Patent Law, 5 AM. J. LeGAL HisT. 309, 320 (1961) ("A number of inventors expected that the new Congress would secure their rights by passing private laws, one for each of their respective inventions. The states had issued patents in such form.").

36. WALTERSCHEID, supra note 6 , at $82-83$. 
lodged by John Churchman, to an ad hoc committee of House members. ${ }^{37}$ The committee interviewed Churchman and, reporting that "his ideas on the subject [of his invention] appear to be ingenious," the committee recommended that "a law should pass to secure to Mr. Churchman, for a term of years, the exclusive pecuniary emolument to be derived from the publication of [his] several inventions." 38 The vital thing to note here is that the House, in exercising the patent power directly, answered implicit questions of procedure (e.g., what papers to consider; whether, and how, to interview the inventor; whether to use one patent to protect multiple inventions) as well as questions of substance (e.g., what threshold level of utility, and of ingeniousness, to require). As more petitions arrived in the House, committee work continued. ${ }^{39}$ Only by enacting a general law in 1790, which directed applicants to a patent board in the Executive Branch, did Congress spare itself the need to establish regular procedures for handling what would doubtless have been a rising tide of inventor petitions seeking utility patents by private bill.

Even after it enacted the first general patent law, Congress continued to exercise the patent power in an individualized way-specifically, to grant patent term extensions by private bill for specific patents. "Between 1808 and 1836, eleven private laws were passed granting term extensions for individual patents." 40 This practice, too, embraced both procedural and substantive dimensions. Indeed, "[i]n response to numerous petitions for extension or renewal, Congress in 1832 finally statutorily established the conditions under which it would consider such petitions." 41 Section 2 of the statute set down requirements about timing, public notice, and the supporting disclosures:

[A]pplication to Congress to prolong or renew the term of a patent, shall be made before its expiration, and shall be notified at least once a month, for three months before its presentation, in two newspapers printing in the city of Washington .... The petition shall set forth particularly the grounds of the application. It shall be verified by oath; the evidence in its support may be taken before any judge or justice of the peace; it shall be accompanied by a statement of the ascertained value of the discovery, invention, or improvement, and of the receipts and expenditures of the patentee, so as to

37. Id.

38. 3 DOCumentaRy History of THE First Federal Congress of THE UNITED States OF AMERICA 28-29 (Linda Grant DePauw et al. eds., 1977).

39. See WALTERSCHEID, supra note 6 , at 84-87.

40. Tyler T. Ochoa, Patent and Copyright Term Extension and the Constitution: A Historical Perspective, 49 J. CoPYRIGHT SOC'Y U.S.A. 19, 52 (2001).

41. WALTERSCHEID, supra note 6 , at 313 . 
exhibit the profit or loss arising therefrom. ${ }^{42}$

This procedural statute, which shaped the inputs that Congress would assess, demonstrates the inevitability of procedural requirements within a general patent regime for an innovation-hungry, market-driven republic like our own. And, although this particular statute was long ago repealed, ${ }^{43}$ Congress continues to extend the terms of individual patents legislatively, using whatever procedural and substantive standards it deems best in the circumstances. ${ }^{44}$

The patent power's procedural component did not, of course, disappear when Congress delegated the review of patent applications to the Executive. Procedural power flowed, inexorably, to the Executive. For example, under the 1790 Patent Act, the patent board "gradually developed a few rules and regulations, as to matters of form as well as to matters of substance." 45 At its second meeting, the board "instructed several inventors who were present to provide models of their inventions," and it requested more information, in varied forms, from the inventors with whom it met in the succeeding weeks. ${ }^{46}$ Such practices (applicant interviews, disclosure requests) ripened into regular procedure. Under the 1793 Act, which changed the Executive's role from one of examining compliance with substantive requirements to one of managing a registration system (with court review of substantive validity in any later infringement case), ${ }^{47}$ Secretary of State Thomas Jefferson established a standard form for the patent document (to which an applicant-drafted

42. Act of July 3,1832, ch. $162, \S 2,4$ Stat. 559, 559.

43. Act of July 4, 1836, ch. 357, $\S 21,5$ Stat. 117, 125 (providing "that all acts and parts of acts heretofore passed on this subject, be, and the same are hereby repealed").

44. See Ochoa, supra note 40, at 76-86 (detailing recent private bills and other extension mechanisms).

45. Federico, supra note 5, at 242.

46. WALTERSCHEID, supra note 6, at 179. Walterscheid concludes, from his review of the extant materials, that "the board seems to have spent a considerable amount of time and effort trying to get more information from inventors." Id. at 181.

47. Act of Feb. 21, 1793, ch. 11, 1 Stat. 318. "Gone was the patent board and consideration of patent petitions by top-rank cabinet members. Under the 1793 regime, patents were handled by clerks of the State Department, and by the Patent Office, established by Madison as a subdivision ... in 1802." Bracha, supra note 35, at 227.

By 1802 it was obvious that patent matters could no longer be handled routinely and that an administrator of unique ability was needed to oversee their issuance. To this post Secretary of State James Madison appointed William Thornton... [who] had both the intellect and the administrative ability needed to guide the fledgling bureau through its early years. He served until his death in 1828.

Daniel Preston, The Administration and Reform of the U.S. Patent Office, 1790-1836, 5 J. EARLY REPUBLIC 331, 334 (1985). 
"schedule" describing the invention would be attached). ${ }^{48}$ A Patent Office pamphlet published in 1811 directed the use of a similar basic form. ${ }^{49}$ Under the 1836 Act, which reinstated a full examination system, Commissioner Henry Ellsworth quickly published a procedures pamphlet entitled Information to Persons Having Business to Transact at the Patent Office. ${ }^{50}$ Ellsworth not only provided information about the new Patent Act, he also set out rules for applicants - stating, for example, that "[w]hen the specifications refer to the drawings, duplicates of them are required, as one must accompany the patent when issued, as explanatory of it, and one must be kept on file in the office." 51

Admittedly, none of these rules packages approaches the complexity and detail of Title 37 of the Code of Federal Regulations, under which patent applicants now operate. All, however, show that, from the beginning, the executive officials empowered to grant applications under our Patent Acts have established procedural rules for handling those applications fairly and efficiently.

The Office acted out of necessity in promulgating procedural rules, for the Patent Acts themselves focused on substantive patentability standards and top-level features of the patent system, rather than the fine details of examination procedure. Consider, again, the 1836 Patent Act. ${ }^{52}$ Its twenty-one sections occupy approximately eight pages in the Statutes at Large. In $\S \S 1$ to 4 , it creates both the Office and the Commissioner and clerk positions, and addresses formal matters such as employee oaths and bonds, the Office seal, and the charge for certified copies of official documents. Section 5 prescribes the form of the issued patent document. Section 9 sets application fees, $\S 10$ makes a pending application inheritable, and $\S 11$ makes a patent assignable by a writing. Sections 14 to 17 address court jurisdiction over infringement suits, as well as the cognizable defenses and allowable remedies in such cases. Section 19

48. Karl B. Lutz, Evolution of U.S. Patent Documents, 19 J. PAT. OFF. SOC'Y 390, 396-97 (1937) (describing the form); see id. at 408-09 (reproducing the standard form, with an explanatory memorandum from Secretary Jefferson to Attorney General Edmund Randolph).

49. William Thornton, Patents (1811), reprinted in $6 \mathrm{~J}$. Pat. OfF. Soc'y 98, 101 (1923).

50. The pamphlet was reprinted, for example, in the August 1836 issue of the foumal of the American Institute. HENRY L. ElLSWORTH, INFORMATION TO PERSONS HAVING BUSINESS to Transact at The Patent OfFice (1836), reprinted in $1 \mathrm{~J}$. AM. INST. 586 (1836), available at http://books.google.com/books?id=FAlAAAAAYAAJ\&dq=\%22Information $\% 20$ to $\% 20$ Persons $\% 20$ Having $\% 20$ Business $\% 20$ to $\% 20$ Transact $\% 20$ at $\% 20$ the $\% 20$ Patent $\% 200$ ffice $\%$ $22 \& p g=P A 586 \# v=$ onepage $\& q \& \mathrm{f}=$ false.

51. Id. at 588 .

52. Act of July 4, 1836, ch. 357, 5 Stat. 117. 
establishes a library for the Office, $\S 20$ obliges the Commissioner to display the models of inventions the Office receives, and $\$ 21$ repeals prior patent statutes and provides transition rules for pending patent applications and court actions. In short, the bulk of the Act focuses on matters other than the details of how the Office is to carry out its primary job, the detailed examination of patent applications to determine whether they meet substantive patentability standards.

The core of the 1836 Act- $\$ \S 6$ through 8 -establishes the substantive standards for patentability ${ }^{53}$ and the basic framework for Office examination of an applicant's eligibility for patent protection. ${ }^{54}$ Section 6 does require the application to be in writing, but says nothing about the form of that writing. Indeed, it does not even specify the particular language in which the application should be provided. Section 6 also requires an applicant to submit drawings "where the nature of the case admits of drawings" without stating who makes that determination or how to do so; similarly, it requires an applicant to "furnish a model ... in all cases which admit of a representation by a model," without providing who determines the propriety of a model or how to do so. ${ }^{55}$ Perhaps most striking, $\S 7$ sets a basic framework for the Office to examine an application for patentability, including an applicant's right to respond to an initial rejection and right to appeal to a board of examiners, but does not state a single time period, timeline, or deadline for doing so. Section 8 requires the Office to decide who among interfering applicants to the same subject matter has priority as the true first inventor, but says nothing about how to make such a determination. Such bare bones demand more detailed implementation procedures. ${ }^{56}$ If the Office did not provide them, who would?

Congress, by delegating patent examination to the Executive in broad terms, made Office-promulgated procedural rules inevitable. The

53. In today's patent law terminology, $\S 6$ requires utility, novelty, and an adequately detailed supporting disclosure. Cf. 35 U.S.C. $\S \S 101$ (requiring utility), 102 (requiring novelty), 112 (requiring adequate supporting disclosure).

54. Act of July 4, 1836, ch. 357, §§ 6-8, 5 Stat. 117, 119-20.

55. Id. $\S 6$.

56. See 2 William C. Robinson, The law of Patents for Useful Inventions $\S 422$, at 8 (1890) ("The proceedings relating to the grant of letters-patent are regulated in part by the acts of Congress, and in part by rules established by the Patent Office itself. While the general features of these proceedings may properly be made the subject of permanent provisions in the statutes, their numerous and ever varying details can be controlled only by the vigilant and flexible authority of the department in which they arise. For this reason power has been conferred upon the Commissioner of Patents to adopt such regulations as he may deem expedient for the conduct of the business committed to his charge."). 
regulatory grant in the 1870 Patent Act was, in a sense, simply an acknowledgment of facts already on the ground: "The 1870 [Patent Office] rules, although they professed to be under the amended laws of $1870 \ldots$, were quite similar to the rules of 1869."57 The allocation thereafter, at any rate, is plain: Congress sets the substantive standards of patentability, and the Patent Office prescribes procedures for examining applications for compliance with those patentability standards.

This substance-procedure allocation, like every such allocation, separates in name things that remain interrelated in fact. It is widely acknowledged, for example, that "virtually all procedural rules may, and on occasion do, affect the result of the litigation."58 As then-Professor Easterbrook put it, "[s]ubstance and process are intimately related. The procedures one uses determine how much substance is achieved, and by whom." 59 For example, "[w] hen the discovery rules were adopted in 1938, they were expected to make a trial less about sport and ambush, and more about truth and evidence. "This presupposed that [those rules] would change the results in many cases." 60 Or, to take an example from contemporary patent law, consider this: the patent application document that one files with the Patent Office must "[b]e in the English language."61 This requirement does not appear in the Patent Act. Instead, it originates from a Patent Office regulation. If it is a valid rule, it is valid because it is

57. Herbert C. Wamsley, The Rulemaking Power of the Commissioner of Patents and Trademarks (Part I), 64 J. Pat. Off. Soc'Y 490, 500 (1982); see also LeVIn H. CAMPBell, The Patent System of The United States so Far as It Relates to the Granting of Patents: A HISTORY 50 (1891) ("The law of 1870 ... gave the Commissioner authority, subject to the approval of the Secretary of the Interior, to establish regulations for the conduct of proceedings in the Office. As early as 1828 the Office began to print for free distribution circulars containing information as to what the law relating to the issuing of patents was, and how to proceed to obtain a patent. These circulars were revised and enlarged from time to time, as various changes and additions were made in the law affecting the practice before the Office. The information contained in them was divided into numbered sections and conveniently arranged under suitable headings. At length these circulars took the form of a pamphlet, which began to be called the Rules of Practice, but prior to the act of 1870 the rules did not have the force of law.").

58. Henry M. HaRt, Jr. \& Herbert Wechsler, The Federal Courts and the FEDERAL SYSTEM 678 (1953); see also Hanna v. Plumer, 380 U.S. 460, 475 (1965) (Harlan, J., concurring) (observing that "any rule, no matter how clearly 'procedural,' can affect the outcome of litigation if it is not obeyed"); Miss. Publ'g Corp. v. Murphree, 326 U.S. 438, 445 (1946) ("Undoubtedly most alterations of the rules of practice and procedure may and often do affect the rights of litigants.").

59. Frank H. Easterbrook, Substance and Due Process, 1982 SuP. CT. REV. 85, 112-13.

60. Thomas O. Main, The Procedural Foundation of Substantive Law, 87 WASH. U. L. REv. 801,819 (2010) (quoting Charles Alan Wright, Procedural Reform: Its Limitations and its Future, 1 GA. L. REV. 563, $570(1967))$.

61. 37 C.F.R. $\S 1.52($ b) (1)(ii) (2009). 
not substantive, but procedural, at least for purposes of $\S 2(\mathrm{~b})(2)(\mathrm{A})$. Of course, the requirement that applicants present their applications in the English language is procedural in that it regulates the formal manner in which an applicant presents her patent claims for examination, in much the same way that the rules about paper type and margins, ${ }^{62}$ the sequence of application components, ${ }^{63}$ and drawings ${ }^{64}$ do. The requirement also has profound substantive consequences, however, because the numbered claim paragraphs at the close of every patent define the very substance of the patentee's right to exclude others from his or her invention. ${ }^{65}$ Indeed, "[t]he first step in any [patent] invalidity or infringement analysis is claim construction."66 Choosing English for Patent Office proceedings, then, plainly contributes to fair and efficient patent examination, and equally plainly affects the scope of the resulting patent rights.

Procedural choices affect substantive outcomes. As a result, were we to use the "affects substance" criterion for sorting Patent Office rules into the substance and procedure categories, the procedure category would collapse to an empty set. But Congress has explicitly ruled out treating procedure as an empty set by the very act of splitting the patent power's applicationprocessing role off from the patentability-defining role and delegating the former to the Patent Office, along with the power to promulgate procedural rules. The trial court in Tafas, by leaning so heavily on an "affects substance" sorting standard,67 sharply curtailed the Office's regulatory power in the teeth of the Patent Act's basic allocation of responsibilities. The Federal Circuit panel in Tafas II, by contrast, had the good sense to reject this antistatutory standard. 68

What sorting standard should the courts use in policing the boundary the Patent Act creates between valid procedural rules and invalid substantive

62. 37 C.F.R. § 1.52(a)(1)(i)-(ii).

63. 37 C.F.R. $\$ \S 1.71-1.75,1.77$.

64. 37 C.F.R. $\S \S 1.83-1.84$.

65. See Markman v. Westview Instruments, Inc., 517 U.S. 370, 373-74 (1996) (describing the patent claim's function in defining the scope of the patentee's grant). As one commentator recently put it, "[a]sk any patent lawyer what the most important part of a patent is, and the answer will invariably be 'the claims." Tun-Jen Chiang, Fixing Patent Boundaries, 108 MiCH. L. REV. 523, 524 (2010) (footnote omitted).

66. Rockwell Int'l Corp. v. United States, 147 F.3d 1358, 1362 (Fed. Cir. 1998).

67. Tafas $I, 541$ F. Supp. 2d 805, 814 (E.D. Va. 2008), affd sub nom. Tafas II, 559 F.3d 1345 (Fed. Cir. 2009), vacated en banc, Tafas III, 328 Fed. App'x 658 (Fed. Cir. 2009) (appeal reinstated).

68. See Tafas II, 559 F.3d 1345, 1354 (Fed. Cir. 2009) ("Substantive rules certainly 'affect individual rights and obligations,' but that inquiry does not necessarily distinguish most procedural requirements, which will also 'affect individual rights and obligations.'”), vacated en banc, Tafas III, 328 Fed. App'x 658 (Fed. Cir. 2009) (appeal reinstated). 
rules? I take up this question next.

\section{FITTING THE BEST MODEL}

Common sense and experience indicate that "substance and procedure differ even if, at the margin, they become difficult to distinguish."69 They differ as follows: "Substantive law refers to that body of principles designed to regulate primary human activity; procedural law refers to that body of principles designed to provide a means for adjudicating controversies over rights derived from the substantive law."70 Thus, for example, the requirement that an invention must be nonobvious to be patentable ${ }^{71}$ and the patentee's right to sue an infringer ${ }^{72}$ are clearly on the substantive side of the line, whereas the required use of white paper for a patent application $^{73}$ and the availability of interrogatories in a patent infringement suit $^{74}$ are just as clearly on the procedural side of the line.

Some matters, however, "are rationally capable of classification as either" substance or procedure. 75 They effectively "fall within a twilight zone between both classifications."76 In this twilight area we see courts calibrate the standards they use for sorting procedure from substance, according to the function that sorting serves in a given context. ${ }^{77} \mathrm{My}$

69. Paul D. Carrington, "Substance" and "Procedure" in the Rules Enabling Act, 1989 DuKE L.J. 281, 284; see also Edgar H. Ailes, Substance and Procedure in the Conflict of Laws, 39 MicH. L. REV. 392, 413 (1941) ("All procedural rules affect substantive rights; the question is one of degree and, since this cannot practicably be debated in every case, the orthodox distinction is valuable.").

70. Allan Ides, The Supreme Court and the Law to Be Applied in Diversity Cases: A Critical Guide to the Development and Application of the Erie Doctrine and Related Problems, 163 F.R.D. 19, 82 (1995); see also Thomas W. Merrill \& Kathryn Tongue Watts, Agency Rules with the Force of Law: The Original Convention, 116 HARV. L. REV. 467, 477 (2002) ("Substantive rules regulate the primary behavior of parties outside the walls of the issuing agency-addressing how much pollution they can emit, what they must disclose in proxy statements, and so forth. . . . Procedural rules, in contrast to substantive rules, govern what happens inside an agencyhow it is organized, how it conducts hearings, and so forth."). Courts describe the distinction in similar terms. See, e.g., Sims v. Great Am. Life Ins. Co., 469 F.3d 870, 883 (10th Cir. 2006); In re Fla. R. Crim. P., 272 So. 2d 65, 65-66 (Fla. 1972).

71. 35 U.S.C. $\$ 103(2006)$.

72. 35 U.S.C. $\S 271$.

73. 37 C.F.R. $\S 1.52(\mathrm{a})(\mathrm{l})(\mathrm{i})(2009)$.

74. FED. R. GIV. P. 33.

75. Hanna v. Plumer, 380 U.S. 460, 472 (1965).

76. Carota v. Johns Manville Corp., 893 F.2d 448, 450 (1st Cir. 1990). According to Professor Main, the following "doctrines have long been difficult to classify as either substantive or procedural: statutes of limitation, testimonial privileges, fee-shifting statutes, burdens of proof, the availability of equitable relief, and other remedial matters." Main, supra note 60 , at 813-14 (footnotes omitted).

77. See, e.g., Hanna, 380 U.S. at 466-74 (differentiating the substance-procedure 
discussion here focuses on these twilight cases, for they are the ones likely to generate a court challenge. ${ }^{78}$

What function should courts serve by sorting procedural from substantive rules in the Patent Office context? A durable answer must begin with the recognition that Congress has nearly a free hand in determining what it wants to delegate to the Office as procedure and what it wants to keep for itself (or delegate to the courts for common law elaboration) as substance. ${ }^{79}$ And the courts best aid Congress if they support, rather than undermine, the basic structure of the patent system that the Patent Act creates. As a result, when an applicant challenges an Office rule under $\S 2(b)(2)(A)$, the court should ask, has the Patent Office improperly invaded the patentability policy territory of Congress? Or, instead, has the Office properly sought to establish and preserve a fair and efficient examination system? The courts, if they attend to the purpose of $\S 2(\mathrm{~b})(2)(\mathrm{A})$, should tune their sorting standard so that it preserves this basic allocation of responsibility. Other bases for distinguishing procedure from substance that arise in different contexts, such as ensuring public participation in the rulemaking process or preventing forum shopping in diversity cases, simply do not apply. ${ }^{80}$

To translate the proper court goal, just described, into a workable legal standard that the Office and private parties alike can apply, it helps to distinguish between two distinct errors the Office can make in determining the validity of a given rule and compare them to the analogous errors a court can make when adjudicating a challenge to that rule. Thinking about the possible errors, and possible congressional responses, can highlight which actor - the Office or the court - is in a better position to evaluate a rule's procedural bona fides in the same manner Congress would.

Suppose the Office considers changing the examination rules, and it knows that the change will generate more accuracy gains than process costs. The Office can adopt the rule, or forbear from adopting the rule. Congress, in response, can leave the new rule in place, or countermand it

distinction used in applying the Erie doctrine from the substance-procedure distinction used to test the validity of a Federal Rule of Civil Procedure under the Rules Enabling Act).

78. The Patent Office will not promulgate plainly substantive rules, and patent applicants will not attack plainly procedural rules on $\S 2$ grounds.

79. I concede that, as a formal matter, either Due Process rationality review or the nondelegation doctrine marks the outer boundary of Congress's power to delegate a portion of the patent power to the Office. But those boundaries are on the very distant horizon, given the Patent Act's detailed substantive patentability standards and the Office's regulatory focus on examination for patentability. As for delegating to the courts the common law task of elaborating on the broadly phrased substantive patentability and infringement criteria set forth in the Patent Act, Congress has long done so. See generally Craig Allen Nard, Legal Forms and the Common Law of Patents, 90 B.U. L. REv. 51 (2010).

80. See infra Part III. 
by amending the Patent Act. To simplify the analysis, assume for this hypothetical that Congress responds, primarily, out of the desire to preserve the existing allocation of powers between itself and the Office. ${ }^{81}$ What errors could the Office make? And how would Congress respond? Consider the table below:

\begin{tabular}{|c|c|c|}
\hline \multirow{2}{*}{$\begin{array}{c}\text { Congress would deem } \\
\text { the rule to be } \ldots\end{array}$} & \multicolumn{2}{|c|}{ The Patent Office ... } \\
\cline { 2 - 3 } & Adopts a Rule & Forbears \\
\hline Procedural & Valid & Invalid \\
\hline Substantive & Invalid & Valid \\
\hline
\end{tabular}

The Office can err by forbearing when Congress would not countermand the change, i.e., by failing to make an efficient change to examination in the mistaken belief that Congress would view the change as an invasion of its power to set substantive patent policy. Congress can correct this error, of course, by enacting the change itself, assuming that Congress learns about the error; and, were Congress to consider doing so, the Office (by hypothesis) would support the change in the legislative process. It is not clear, however, how the courts could correct this type of error. ${ }^{82}$

The Office also can err by adopting a rule that Congress would reject, in the mistaken belief that Congress would not view the change as an invasion of its preserve of substantive patent policy. Congress can correct this error by amending the Patent Act, and Congress will learn about the new rule if it falls especially hard on applicants from a particular technology domain. The courts, too, can correct this error, in an action against the Office under the APA. 83

81. Obviously, Congress could respond, or fail to respond, for a host of reasons having nothing to do with the substance-procedure distinction I analyze here. The existence of those other potential reasons, however, does not affect my analysis.

82. Perhaps there is a way for a private party to petition the Office to change its rules and sue if the Office rejected, or failed to act on, the petition. The APA does provide for review of agency failure to act. See 5 U.S.C. $\$ \$ 702,706(1)(2006)$. But it is not at all clear what duty the Office would have violated in such a scenario, and the courts appear to hold petitioners in this context to a very high, mandamus-like standard. See In re Am. Rivers \& Idaho Rivers United, 372 F.3d 413, 418 (D.C. Cir. 2004). The Patent Act's directive that Office regulations "shall facilitate and expedite the processing of patent applications," 35 U.S.C. $\S 2(b)(2)(C)(2006)$, does not seem nearly crisp enough to establish a violated duty in a case where there are good arguments for and against promulgating the proposed rule.

83. 5 U.S.C. $\$ \S 702,706(2)(C)$. The Tafas case was just such an action. See Tafas I, 541 
This is not a domain that cries out for judicial second-guessing. The Office should, if it is concerned with efficiency, minimize the sum of the expected costs of the two foregoing types of errors. Given the Office's long success with its procedural rules, and its ongoing relations with its congressional oversight committees, the Office should have a reasonably strong sense for what Congress will, and will not, allow. And, putting court review to one side, the root criterion of what is procedural for Patent Act purposes is whether "Congress will allow it."

Now assume the Office has gone ahead and actually adopted a new rule governing patent examination. A court reviewing the rule's validity faces a profile of potential hits and misses not unlike the one the Office faced. The court can void the rule or uphold it. The rule itself embodies the Office's assessment that Congress would deem the new rule to be procedural and thus leave it intact. In that sense, the imagined reaction of Congress to the new rule is key to both error profiles. The court, however, is a step further removed from Congress in this scenario. The court is, in effect, reassessing the Office's assessment of congressional reaction. Consider the table below:

\begin{tabular}{|c|c|c|}
\hline \multirow{2}{*}{$\begin{array}{c}\text { The Office thinks that Congress } \\
\text { would deem the rule procedural, } \\
\text { and the Office is ... }\end{array}$} & The court . . \\
\cline { 2 - 3 } & Upholds the Rule & Voids the Rule \\
\hline Correct & Valid & Invalid \\
\hline Incorrect & Invalid & Valid \\
\hline
\end{tabular}

The court can err by voiding a rule that the Office had correctly surmised Congress would leave in place. The court also can err by upholding a rule that the Office had incorrectly concluded Congress would leave in place. Congress can correct either type of court error, at least as to future applications.

As a doctrinal matter, the Federal Circuit gives Chevron deference ${ }^{84}$ to the Patent Office's reasonable exercise of the procedural power so long as it is satisfied that the regulation in question is indeed procedural. ${ }^{85}$ The court,

F. Supp. 2d 805, 808 (E.D. Va. 2008), affd sub nom. Tafas II, 559 F.3d 1345 (Fed. Cir. 2009), vacated en banc, Tafas III, 328 Fed. App'x 658 (Fed. Cir. 2009) (appeal reinstated).

84. See Chevron, U.S.A., Inc. v. Natural Res. Def. Council, Inc., 467 U.S. 837 (1984).

85. Cooper Techs. Co. v. Dudas, 536 F.3d 1330, 1337 (Fed. Cir. 2008) ("Because the Patent Office is specifically charged with administering statutory provisions relating to 'the 
given its relatively greater distance from Congress, should also embrace some form of deference on the prior question whether a challenged regulation is procedural. 86 As a policy matter, court deference makes sense in light of the Office's superior ability and experience - compared to the court - to assess whether Congress would view a particular new rule as an improper invasion of its substantive turf, at least in a case where the Patent Act is ambiguous. (Where the Act is not ambiguous, the Office and the courts alike are bound to follow it. ${ }^{87}$ )

In sum, $\S 2(\mathrm{~b})(2)(\mathrm{A})$ allocates power between Congress and the Patent Office. Congress can fend off invasions from the Office. The Office has long enjoyed success in framing rules that meet with apparent congressional approval, if the lack of countermands is any indication, and its ongoing relations with oversight committees give it helpful guidance for staying on its side of the line between procedure and substance. Courts can play backstop for Congress, policing the substance- - procedure boundary for the (admittedly unlikely) extreme outlier. These arrangements and the error profiles they produce suggest that the standard for distinguishing procedure from substance should give the Office substantial freedom to treat as procedure the matters in the twilight zone between clear procedure and clear substance. Put another way, a court should not void a Patent Office rule as substantive unless it is a rather glaring invasion of Congress's turf

conduct of proceedings in the Office,' we give Cheoron deference to its interpretations of those provisions." (quoting 35 U.S.C. § 2(b)(2)(A))). In Cooper, "the Patent Office ha[d] interpreted a statutory provision ... that created inter partes reexamination and established rules for inter partes reexamination proceedings before the Patent Office," i.e., that "plainly 'govern[s] the conduct of proceedings in the Office' within the meaning of $\S 2(\mathrm{~b})(2)(\mathrm{A}) . "$ Id. at 1336. See generally United States v. Mead Corp., 533 U.S. 218, 226-27 (2001) ("We hold that administrative implementation of a particular statutory provision qualifies for Cheoron deference when it appears that Congress delegated authority to the agency generally to make rules carrying the force of law, and that the agency interpretation claiming deference was promulgated in the exercise of that authority.").

86. Professor Merrill argues persuasively that Skidmore deference fits well for these "scope of agency jurisdiction" questions, at least as to typical agencies. See Thomas W. Merrill, Rethinking Article I, Section 1: From Nondelegation to Excluswe Delegation, 104 Colum. L. REV. 2097, 2174-75 (2004). My sense here, by contrast, is that Skidmore, with its focus on a new regulation's "consistency with earlier and later pronouncements," Skidmore v. Sicift $\mathbb{E}$ Co., 323 U.S. 134, 140 (1944), may bring too heavy a status quo bias to bear on the question whether a given innovation in the Patent Office examination process runs afoul of the substance procedure line in $\S 2(\mathrm{~b})(2)(\mathrm{A})$. Unprecedented Patent Office filing rates and backlogs may well call for unprecedented procedural mechanisms. My goal here is to explore a different model for measuring the reach of the Patent Office's regulatory writ, one not confined to the Skidmore-Chevron deference continuum.

87. See, e.g., Wyeth v. Kappos, 591 F.3d 1364, 1369-70 (Fed. Cir. 2010) (concluding, contra the Patent Office, that the patent term extension provision at 35 U.S.C. $\S 154(\mathrm{~b})$ is unambiguous). 
that lacks any credible examination management rationale. And a court should uphold a rule against a $\S 2$ attack where the Office can explain the way in which that rule reasonably helps the Office establish or preserve a fair and effective examination process for applicants, notwithstanding some incidental effects on applicants' substantive rights.

The courts have not yet used this standard for distinguishing procedure from substance under the Patent Act. In Tafas II, the Federal Circuit's most recent effort to articulate a sorting standard, the panel opinion (now vacated) adapted the APA-based sorting standard the D.C. Circuit used in $7 E M$ Broadcasting Co. v. FCC. ${ }^{88} \quad \mathcal{J} E M$ involved a challenge to a rule the Federal Communications Commission (FCC) had issued without notice-andcomment, i.e., without providing the opportunity for public participation mandated by $\S 553$ of the APA. According to the Federal Circuit in Tafas $I I$, adapting $\mathcal{J E M}$,

the Final Rules challenged in this case are procedural. In essence, they govern the timing of and materials that must be submitted with patent applications. The Final Rules may "alter the manner in which the parties present ... their viewpoints" to the USPTO, but they do not, on their face, "foreclose effective opportunity" to present patent applications for examination. 89

Even though it was "most persuaded in this case by the D.C. Circuit's approach in $\mathcal{f} E M, " 90$ the court was also at pains to underscore that it " $\mathrm{d}[\mathrm{id}]$ not purport to set forth a definitive rule for distinguishing between substance and procedure."9l Admittedly, the Tafas II panel opinion would not have had a different bottom-line result if the Federal Circuit had used the framework I outline above. The case would, however, have provided a robust standard for future cases, rather than an explicit flight from any "definitive rule."

It is, of course, fair to ask whether the courts have confronted a substance-procedure distinction analogous to the Patent Act's, and whether, in that other domain, the courts afford the procedural rulemaker the kind of leeway I urge for the Patent Office. The short answer to both

88. $7 E M, 22$ F.3d 320 (D.C. Cir. 1994).

89. Tafas II, 559 F.3d 1345, 1356 (Fed. Cir. 2009), (quoting JEM, 22 F.3d at 328) (omission in the original), vacated en banc, Tafas III, 328 Fed. App'x 658 (Fed. Cir. 2009) (appeal reinstated). I have quite a bit more to say below about $\mathcal{J} E M$, and about the substance-procedure distinction that $\S 553$ of the APA creates. See infra Part III.

90. Tafas II, 559 F.3d at 1355 .

91. Id. at 1356. One can hope this is judicial humility, rather than an effortunconscious or not- to keep case-by-case court review the main event in any major Patent Office rulemaking process. In any event, both the Office and the public would be better served by the humility of a clearly stated general standard that they can apply and predict. 
questions is, "yes."

The analogous distinction is the one Congress established in the Rules Enabling Act (REA), ${ }^{92}$ first enacted in $1934 .{ }^{93}$ The literature on the REA is vast and rich. ${ }^{94}$ It is not my aim to canvass it in detail here, much less to take sides in the many nuanced debates it contains. Rather, my goal is simply to show the way in which the Supreme Court's REA jurisprudence provides a ready template that fits the sorting function the Patent Act's structure suggests. The Patent Act is, in effect, a rules enabling act.

One last point before discussing the REA: The legislative history of the 1870 Patent Act - the original source of the $\S 2$ standard - supports the view that courts should analyze the scope of the Patent Office's power to make rules for the conduct of proceedings in the Office along the same lines that courts use to analyze the Supreme Court's power under the REA to make rules for the conduct of federal litigation. Specifically, during a floor debate in the House, "Congressman Jenckes, who was the committee chairman and the sponsor of the pending legislation," 95 described the new grant of regulatory power to the Office this way:

$[\mathrm{T}]$ he power which the Commissioner shall have and ought to have shall be that of regulating the manner in which proceedings shall be conducted in his office; the rules of court, so to speak, not the rules of decision but of government. ${ }^{96}$

At least one congressman, then, thought of the Office's regulatory power as akin to the power to make rules of court.

The Rules Enabling Act provides both that " $[\mathrm{t}]$ he Supreme Court shall

92. 28 U.S.C. $\S 2072(2006)$.

93. Act of June 19, 1934, ch. 651, 48 Stat. 1064.

94. The articles I have found especially instructive are as follows: Robert G. Bone, Making Effective Rules: The Need for Procedure Theory, 61 OKL.A. L. REv. 319 (2008); Robert G. Bone, The Process of Making Process: Court Rulemaking, Democratic Legitimacy, and Procedural Efficacy, 87 GEo. LJ. 887 (1999); Stephen B. Burbank, Hold the Corks: A Comment on Paul Carrington's "Substance" and "Procedure" in the Rules Enabling Act, 1989 DukE L.J. 1012; Stephen B. Burbank, Procedure, Politics and Power: The Role of Congress, 79 Notre Dame L. REv. 1677 (2004); Burbank, supra note 21; Carrington, supra note 69; Ely, supra note 20; Ides, supra note 70; Mary Kay Kane, The Golden Wedding Year: Erie Railroad Company v. Tompkins and the Federal Rules, 63 Notre Dame L. Rev. 671 (1988); Leslie M. Kelleher, Taking "Substantive Rights" (in the Rules Enabling Act) More Seriously, 74 NOTRE DAME L. REV. 47 (1998); Martin H. Redish \& Uma M. Amuluru, The Supreme Court, the Rules Enabling Act, and the Politicization of the Federal Rules: Constitutional and Statutory Implications, 90 MINN. L. REv. 1303 (2006); Martin H. Redish \& Dennis Murashko, The Rules Enabling Act and the Procedural-Substantive Tension: A Lesson in Stalutory Interpretation, 93 MINN. L. REV. 26 (2008); Stephen N. Subrin, How Equity Conquered Common Law: The Federal Rules of Civil Procedure in Historical Perspective, 135 U. PA. L. REV. 909 (1987).

95. Wamsley, supra note 57 , at 494.

96. Cong. Globe, 41st Cong., 2D Sess. 2856 (1870) (emphasis added). 
have the power to prescribe general rules of practice and procedure" for federal trial and appeals courts, and that "[s]uch rules shall not abridge, enlarge or modify any substantive right."97 "Taken together, the goal of these two [requirements] is to ensure that any given federal rule is, in fact, a rule of procedure and not a disguised rule of substantive law." 98 In other words, Congress "intended to allocate lawmaking power between the Supreme Court as rulemaker and Congress."99 Sound familiar? It tracks the congressional division of the patent power between the Patent Office and Congress.

The Court has upheld this delegation of rulemaking power from Congress. ${ }^{100}$ Summarizing current doctrine, Redish and Amuluru describe the Supreme Court's broad implementation of the REA-delegated rulemaking power this way:

Recognizing that the Rules will often have incidental impacts on substantive concerns, the Court has confined the Act's substantive right limitation to exclude from its reach primarily procedural rules whose impact beyond the courthouse walls is merely incidental. This is so, even if that incidental and unintended substantive impact is substantial. ${ }^{101}$

Generally speaking, the analysis tilts strongly in favor of upholding a Rule. ${ }^{102}$ With this summary in view, it is helpful to trace the major cases

97. 28 U.S.C. $\S 2072(a)$ (b). The Rules process also has, as a formal matter, an explicit window for congressional disapproval of proposed Rules, but there is less to it than meets the eye. See infra notes $134-38$ and accompanying text.

98. Ides, supra note 70 , at 30 .

99. Burbank, supra note 21, at 1106; see also id. at 1113 ("The purpose of the procedure/substance dichotomy is ... to allocate policy choices - to determine which federal lawmaking body, the Court or Congress, shall decide whether there will be federally enforceable rights regarding the matter in question and the content of those rights."); Elizabeth T. Lear, Congress, the Federal Courts, and Forum Non Conveniens: Friction on the Frontier of the Inherent Power, 91 IowA L. REV. 1147, 1180 (2006) ("The Rules Enabling Act establishes a detailed mechanism through which the Court may create procedural law with input from Congress, reserving to Congress the right to enact prospective federal legislation implicating substantive rights.").

100. See Willy v. Coastal Corp., 503 U.S. 131, 136 (1992) ("Article I, § 8, cl. 9, authorizes Congress to establish the lower federal courts. From almost the founding days of this country, it has been firmly established that Congress, acting pursuant to its authority to make all laws 'necessary and proper' to their establishment, also may enact laws regulating the conduct of those courts and the means by which their judgments are enforced." (quoting U.S. ConsT. art. I, § 8, cl. 18)); Sibbach v. Wilson \& Co., 312 U.S. 1, 9-10 (1941) ("Congress has undoubted power to regulate the practice and procedure of federal courts, and may exercise that power by delegating to this or other federal courts authority to make rules not inconsistent with the statutes or constitution of the United States...." (footnotes omitted)).

101. Redish \& Amuluru, supra note 94, at 1333 (footnote omitted).

102. See Shady Grove Orthopedic Assocs. v. Allstate Ins. Co., 130 S. Ct. 1431, 1442-43 
whereby the Court, applying the REA, arrived at this approach to sorting valid procedural rules from invalid substantive encroachments on congressional power.

The Supreme Court first considered an REA-based challenge to a Federal Rule of Civil Procedure in Sibbach v. Wilson $\&$ Co. ${ }^{103}$ Sibbach brought a tort claim in diversity in Illinois federal court arising from an accident that took place in Indiana. The court, upon the defendant's request, ordered Sibbach to submit to a physical examination by a physician pursuant to Rule 35. Affirming that the Federal Rules are within the power of Congress to regulate federal court procedure and to delegate rulemaking to the courts, and that a valid Rule "has the force of a federal statute," the Court considered two REA constraints for a valid Rule. ${ }^{104}$ Was the Rule one of "practice and procedure"? The Court thought so, ${ }^{105}$ offering little analysis on the point, and that seems correct: the Rule "was a rule of practice or procedure in the sense that it provided a method of discovery directed toward the resolution of an underlying substantive claim."106 Did the Rule abridge any substantive right of Sibbach's, in violation of the REA, even assuming it contradicted her right in Illinois state court to be free of such a compelled physical examination? ${ }^{107}$ The Court thought not:

The test must be whether a rule really regulates procedure,- the judicial process for enforcing rights and duties recognized by substantive law and for justly administering remedy and redress for disregard or infraction of them.

That the rule[] in question [is] such is admitted. ${ }^{108}$

Rule 35 altered a state procedural rule, not a substantive right. ${ }^{109}$ It thus passed muster under the REA.

(2010) (plurality opinion) ("W]e have rejected every statutory challenge to a Federal Rule that has come before us. .. . Each of these rules had some practical effect on the parties' rights, but each undeniably regulated only the process for enforcing those rights; none altered the rights themselves, the available remedies, or the rules of decision by which the court adjudicated either.").

103. 312 U.S. 1 (1941).

104. Id. at 13 .

105. Id. at 11 .

106. Ides, supra note 70 , at 31 .

107. Sibbach, 312 U.S. at 10.

108. Id. at 14; see also Shady Grove Orthopedic Assocs. v. Allstate Ins. Co., $130 \mathrm{~S}$. Ct. 1431,1442 (2010) (plurality opinion) (quoting this portion of Sibbach as the foundation of the framework for analyzing a rule's validity under the Rules Enabling Act (REA)).

109. Professor Ides has described the Sibbach issue this way: "The federal rule at issue ... did not alter the standards of liability pertaining to the primary human activity at issue in the case; rather, it provided a means for determining whether the defendant was liable under those standards." Ides, supra note 70, at 82. 
Five years later, in Mississippi Publishing Corp. v. Murphree, ${ }^{110}$ the Court considered its second REA challenge to a federal Rule. Murphree sued Mississippi Publishing in diversity in Mississippi federal court on a defamation claim. The case turned on the validity of Rule 4, governing the process for validly serving a summons. The publisher argued that the Rule effectively expanded the trial court's jurisdiction. The Supreme Court rejected that contention, notwithstanding the reality that "most alterations of the rules of practice and procedure may and often do affect the rights of the litigants." 11 Did Rule 4 abridge the publisher's substantive rights in violation of the REA? No, because "it $d[i d]$ not operate to abridge . . . the rules of decision by which th[e] court will adjudicate its rights." 112 Indeed, it "relate[d] merely to the manner and the means by which a right to recover is enforced."113 The fact that the Mississippi court with valid jurisdiction, rather than some other court, would adjudicate Murphree's claim did not undermine the Rule: "Congress' prohibition of any alteration of substantive rights of litigants was obviously not addressed to such incidental effects as necessarily attend the adoption of the prescribed new rules of procedure...."114 Like Sibbach, Murphree accommodated rulemaking broadly.

In its 1965 decision in Hanna v. Plumer, ${ }^{15}$ the Court reaffirmed the REA boundary analysis developed in Sibbach and Murphree. ${ }^{116}$ Hanna sued in diversity in Massachusetts federal court on a tort claim arising from a car accident in South Carolina. ${ }^{17}$ Hanna served the deceased defendant's executor validly under Rule 4, but invalidly under a Massachusetts state statute applicable to executors. ${ }^{118}$ Quoting the reasoning from Sibbach and Murphree liberally for support, the Court concluded that the Rule "clearly passes muster. Prescribing the manner in which a defendant is to be notified that a suit has been instituted against him, it relates to the practice and procedure of the district courts." 119 And, after a lengthy discussion disentangling REA analysis from the Erie doctrine's focus on "discouragement of forum-shopping and avoidance of inequitable

110. 326 U.S. 438 (1946).

111. Id. at 445 .

112. Id. at 446 .

113. Id. (internal quotation marks and alteration omitted).

114. Id. at 445 .

115. 380 U.S. 460 (1965).

116. See Kane, supra note 94, at 676.

117. Hanna, 380 U.S. at 461.

118. Id. at $461-62$.

119. Id. at 464 (internal quotation marks omitted). 
administration of the laws,"120 the Court underscored the wide latitude rulemakers have under the REA's two constraints. The "congressional power to make rules governing the practice and pleading in th[e] courts" delegated under the REA "includes a power to regulate matters which, though falling within the uncertain area between substance and procedure, are rationally capable of classification as either."121 A matter in the twilight area between procedure and substance is thus open to regulation by Rule, so far as the REA constraints are concerned.

The post-Hanna Supreme Court cases follow the Hanna pattern. ${ }^{122}$ In Burlington Northern Railroad Co. v. Woods, ${ }^{123}$ a defendant railroad company had removed an Alabama state tort case to federal court. The railroad lost at trial, "posted a bond to stay the judgment pending appeal," and then lost again on appeal.124 The Woods, who had won at trial and on appeal, moved in the Eleventh Circuit for the Alabama state statute-mandated affirmance penalty of $10 \%$ of the money judgment. Reversing the Eleventh Circuit, the Supreme Court held that the mandatory Alabama statute conflicted with the discretionary model established in Federal Rule of Appellate Procedure 38.125 Because the federal rule conflicted with the

120. Id. at 468 .

121. Id. at 472 .

122. For recent REA analyses in the circuit courts, see Morel v. DaimlerChrysler AG, 565 F.3d 20, 24 (1st Cir. 2009); Cohen v. Office Depot, Inc., 184 F.3d 1292, 1299 (1 lth Cir. 1999). The Supreme Court's most recent REA/Erie decision, though fractured, does not call the Hanna pattern into doubt. In that case, Shady Grove Orthopedic Associates. v. Allstate Insurance Co., $130 \mathrm{~S}$. Ct. 1431 (2010), the Court split 5-4 on the threshold question whether Federal Rule of Civil Procedure 23 conflicted with the New York state statute that defendant Allstate Insurance sought to apply in a diversity-based federal class action. The majority concluded the Federal Rule and state statute "flatly contradict each other," $i d$. at 1441, whereas the dissenters "perceive[d] no unavoidable conflict between" them, id. at 1469 (Ginsburg, J., dissenting). The majority itself, however, split 4-1 on the question of how best to analyze whether Rule 23 , having trumped the conflicting state statute, is valid under the REA. Id. at 1449-51 (Stevens, J., concurring in part and concurring in the judgment). The plurality applied Hanna, id. at 1442-43, but there is no majority opinion on the REA question.

123. 480 U.S. 1 (1987).

124. Id. at 2 .

125. "If a court of appeals determines that an appeal is frivolous, it may, after a separately filed motion or notice from the court and reasonable opportunity to respond, award just damages and single or double costs to the appellee." FED. R. APP. P. 38. The Rule was amended in 1994 to provide for pre-imposition notice and an opportunity to respond. Other than that, the present Rule is the same as the one the Court evaluated in Burlington Northern. See 480 U.S. at 4 ("Entitled 'Damages for delay,' Rule 38 provides: 'If the court of appeals shall determine that an appeal is frivolous, it may award just damages and single or double costs to the appellee."'). 
Alabama statute that would otherwise have applied in this diversity case, ${ }^{126}$ the Court tested its validity. Did it regulate procedure? Yes: "Federal Rule 38 regulates matters which can reasonably be classified as procedural, thereby satisfying the constitutional standard for validity.... The choice made by the drafters of the Federal Rules in favor of a discretionary procedure affects only the process of enforcing litigants' rights and not the rights themselves." 127 Did it abridge a substantive right? No: "The cardinal purpose of Congress in authorizing the development of a uniform and consistent system of rules governing federal practice and procedure suggests that Rules which incidentally affect litigants' substantive rights do not violate this [anti-abridgment] provision if reasonably necessary to maintain the integrity of that system of rules." 128

Most recently, in Business Guides, Inc. v. Chromatic Communications Enterprises, Inc., the Court upheld Rule 11 sanctions against a copyright plaintiff who failed to adequately investigate its infringement claim before filing its case and requesting a temporary restraining order. ${ }^{129}$ The sanctioned plaintiff argued, among other things, that "imposing sanctions against a represented party that did not act in bad faith violates the Rules Enabling Act."130 Noting that this REA challenge "ha[d] a large hurdle to get over," the Court applied Hanna and Burlington: "There is little doubt that Rule 11 is reasonably necessary to maintain the integrity of the system of federal practice and procedure, and that any effect on substantive rights is incidental."'l31

The pattern is plain. In all these cases there were, of course, reasonable arguments that the challenged rules were substantive, not procedural. In that sense, the cases were hard; indeed, the Supreme Court likely would have refused review had it been otherwise. But in each case the Court gave wide berth to REA rulemaking. If a rule regulates a matter that one can reasonably classify as procedural, it is valid under the REA, notwithstanding incidental effects the rule may have on a litigant's substantive rights. Congress can, of course, change any rule it likes, either by stopping a proposed rule from going into force or by passing a procedural statute that creates a rule directly. ${ }^{132}$

126. Burlington Northern, 480 U.S. at 7.

127. Id. at 8 .

128. Id. at 5 .

129. 498 U.S. 533, 554 (1991).

130. Id. at 551 (citation omitted).

131. Id. at 552.

132. Shady Grove Orthopedic Assocs. v. Allstate Ins. Co., 130 S. Ct. 1431, 1438 (2010) ("Congress ... has ultimate authority over the Federal Rules of Civil Procedure; it can create exceptions to an individual rule as it sees fit-either by directly amending the rule or 
The courts should verify the procedural bona fides of Patent Office rules using the same standard. To wit: A Patent Office rule that incidentally affects applicants' substantive rights nevertheless passes muster under $\S 2(b)(2)(A)$ of the Patent Act if the rule is reasonably necessary to establish or preserve the fair and effective patent examination process that the Office's rules must organize. ${ }^{133}$

One might object to adapting the REA sorting standard for use in the Patent Act context on the ground that the federal court rulemaking process, unlike the Office's rulemaking process, expressly provides for a period of congressional review before a new court rule takes effect. According to the statute,

[t]he Supreme Court shall transmit to the Congress not later than May 1 of the year in which a rule prescribed under section 2072 is to become effective a copy of the proposed rule. Such rule shall take effect no earlier than December 1 of the year in which such rule is so transmitted unless otherwise provided by law. ${ }^{134}$

One could argue that, under this provision, the failure of Congress to prevent a rule from taking effect is strong evidence that Congress thinks the rule is on the right side of the line between procedure and substance. In Sibbach, in fact, the Supreme Court expressed just this view. ${ }^{135}$ This makeweight has largely vanished from the Court's REA cases, however, and - although a duly promulgated rule is presumptively valid - there is no question that a litigant harmed by the rule can challenge its validity. Moreover, although it disavowed the technique early on, ${ }^{136}$ the Court now uses the REA's bar on changing substantive rights as a policy canon when

by enacting a separate statute overriding it in certain instances.").

133. The Patent Office, in its opening appeal brief at the Federal Circuit in the Tafas II case, devoted two pages to arguing that the Office's rules were procedural under the RFA, Sibbach, Murphree, and Hanna: "Here, the Final Rules clearly fall on the procedural side of the line drawn by Hanna." Brief for Appellants at 36-37, Tafas II, 559 F.3d 1345 (Fed. Cir. 2009) (No. 2008-1352), vacated en banc, Tafas III, 328 Fed. App'x 658 (Fed. Cir. 2009) (appeal reinstated). This was too little space, it seems, for developing this alternative argument. The Federal Circuit, in any event, made no mention of the REA theory in the panel opinion.

134. 28 U.S.C. $\S 2074(a)$ (2006). Waiting periods were part of the original REA. Act of June 19, 1934, ch. 651, §§1-2, 48 Stat. 1064, 1064.

135. Sibbach v. Wilson \& Co., 312 U.S. 1, 15-16 (1941). Justice Frankfurter, in dissent, was quite skeptical of the argument, opining that "to draw any inference of tacit approval from non-action by Congress is to appeal to unreality." Id. at 18 (Frankfurter, J., dissenting).

136. See Walker v. Armco Steel Corp., 446 U.S. 740, 750 n.9 (1980) ("This is not to suggest that the Federal Rules of Civil Procedure are to be narrowly construed in order to avoid a 'direct collision' with state law. The Federal Rules should be given their plain meaning. If a direct collision with state law arises from that plain meaning, then the analysis developed in Hanna v. Plumer applies."). 
construing the rules themselves. Specifically, it construes disputed terms in the rules more narrowly to avoid overstepping the REA's prohibition against a rule's abridging, enlarging, or modifying substantive rights. ${ }^{137}$ This policy canon makes no sense if one takes seriously the idea that congressional scrutiny from May to December, under the $\S 2074$ (a) waiting period, largely squares the rule's text with existing substantive law. The policy canon seems, in other words, to acknowledge that congressional acquiescence is a sign of indifference, not a sign of full vetting by Congress. ${ }^{138}$ The fact that the Patent Office promulgates rules without a formal congressional review period is thus no reason to abjure the REA framework in the Patent Act context.

Federal law offers another substance-procedure distinction resembling the one the Patent Act establishes-namely, the EEOC's power to issue procedural rules (but not substantive rules) under Title VII of the Civil Rights Act of 1964.139 "The EEOC was created in 1964 with the enactment of Title VII," and it "has primary enforcement authority over Title VII," as well as other civil rights statutes. ${ }^{140}$ As part of this enforcement regime, the EEOC investigates charges of unlawful discrimination that private parties bring to its attention. ${ }^{141}$ In a recent case challenging a rule that the EEOC had promulgated pertaining to the lodging of charges against an employer, the Supreme Court approached

137. See Ortiz v. Fireboard Corp., 527 U.S. 815, 842 (1999) (adopting a narrower construction of Rule 23(b)(1)(B) on the ground that, among other things, "this limiting construction... minimizes potential conflict with the Rules Enabling Act, and avoids serious constitutional concerns"); id. at 845 ("The Rules Enabling Act underscores the need for caution."); Amchem Prods., Inc. v. Windsor, 521 U.S. 591, 613 (1997) ("Rule 23's requirements must be interpreted in keeping with Article III constraints, and with the Rules Enabling Act, which instructs that rules of procedure 'shall not abridge, enlarge or modify any substantive right,' 28 U.S.C. $§ 2072$ (b)."); Kamen v. Kemper Fin. Serv., Inc., 500 U.S. 90, 96 (1991) ("Indeed, as a rule of procedure issued pursuant to the Rules Enabling Act, Rule 23.1 cannot be understood to "abridge, enlarge or modify any substantive right." (quoting 28 U.S.C. $\$ 2072(b)$ )).

138. In a different context, criticizing the canon against repeal of a statute by implication, Judge Posner made the point crisply: "Congressmen do not carry the statutes of the United States around in their heads any more than judges do." Friedrich v. City of Chicago, 888 F.2d 511, 516 (7th Cir. 1989), vacated, 499 U.S. 933 (1991).

139. 42 U.S.C. $§ 2000 \mathrm{e}-12$ (a) (2006) ("The Commission shall have authority from time to time to issue, amend, or rescind suitable procedural regulations to carry out the provisions of this subchapter.").

140. Melissa Hart, Skepticism and Expertise: The Supreme Court and the EEOC, 74 FORDHAM L. REv. 1937, 1941 (2006); see also 42 U.S.C. § 2000e-4 (creating the Commission), § 2000e5(a) ("The Commission is empowered, as hereinafter provided, to prevent any person from engaging in any unlawful employment practice as set forth in section $2000 \mathrm{e}-2$ or $2000 \mathrm{e}-3$ of this title.").

141. 42 U.S.C. $\S 2000 \mathrm{e}-5(b)$. 
the substance--procedure distinction in a manner similar to its REA cases.

By way of background, a private party initiates EEOC involvement by filing a "charge" with the Commission. Under the statute, "[c]harges shall be in writing under oath or affirmation and shall contain such information and be in such form as the Commission requires." 142 The statute also sets time limits within which a charge must be filed: "within one hundred and eighty days after the alleged unlawful employment practice occurred," or, if the charging party "has initially instituted proceedings with a State or local agency with authority to grant or seek relief" from unlawful employment practices, "within three hundred days after the alleged unlawful employment practice occurred, or within thirty days after receiving notice that the State or local agency has terminated the proceedings under the State or local law, whichever is earlier."143 Title VII does not, however, make clear whether a charge that is lodged with the EEOC before the statutory time has run, but is verified by oath or affirmation after that time has run, is valid or fatally defective. The EEOC, by regulation, relates a subsequent verification back to the date the charge was originally filed. ${ }^{144}$

In Edelman v. Lynchburg College, ${ }^{145}$ the Supreme Court considered the validity of the EEOC's regulation treating a later-verified charge as timely. Edelman, the complaining party, filed his charge with the EEOC 161 days after the alleged discriminatory event but did not verify it until 313 days after that event.146 The Fourth Circuit, affirming the district court's dismissal of Edelman's case, "held that the plain language of the statute foreclosed the EEOC regulation allowing a later oath to relate back to an earlier charge."147 The Supreme Court reversed, concluding that "[t]he statute is ...open to interpretation and the regulation addresses a legitimate question."' 148 Specifically, as a textual matter,

[s]ection [2000e-5(b)] merely requires the verification of a charge, without saying when it must be verified; $\S[2000 \mathrm{e}-5(\mathrm{e})(1)]$ provides that a charge must be filed within a given period, without indicating whether the charge must be verified when filed. Neither provision incorporates the other so as to give a

142. Id. (emphasis added).

143. 42 U.S.C. $\$ 2000 \mathrm{e}-5(\mathrm{e})(1)$.

144. 29 C.F.R. $\$ 1601.12$ (b) (2009) ("A charge may be amended to cure technical defects or omissions, including failure to verify the charge.... Such amendments... will relate back to the date the charge was first received.").

145. 535 U.S. 106 (2002).

146. Id. at 109-10. "In Edelman's case, the filing period was 300 days after the alleged discriminatory practice." Id. at 109.

147. Id at $110-11$.

148. Id. at 113 . 
definition by necessary implication. ${ }^{149}$

The EEOC bridged this statutory gap in procedure as part of its mandate to fairly and efficiently deal with the charges it receives. Indeed, the Court dismissed Lynchburg College's argument that the rule was impermissibly substantive as "really nothing more than a recast of the plain language argument" that the Court found unpersuasive. ${ }^{150}$ Moreover, as a policy matter, the Court approved the EEOC's "reasonable" gap-filling regulation for both "ensur[ing] that the lay complainant, who may not know enough to verify on filing, will not risk forfeiting his rights inadvertently" and "look[ing] out for the employer's interest by refusing to call for any response to an otherwise sufficient complaint until the verification has been supplied."151 Most importantly, for my purposes, the Court analogized the EEOC rule to Federal Rule of Civil Procedure 15(c), concluding that "if relation back is a good rule for courts of law, it would be passing strange to call it bad for an administrative agency." 152 The Court thus viewed the EEOC's procedural regulation through the same lens it views the rules the federal courts promulgate under the REA. There is no reason to approach Patent Office procedural rules any differently.

In sum, the courts should sort procedure from substance in Patent Office rules using the same basic approach the Supreme Court has used in the REA context. Specifically, a Patent Office rule that incidentally affects applicants' substantive rights does not violate $\S 2(\mathrm{~b})(2)(\mathrm{A})$ of the Patent Act if the rule is reasonably necessary to establish or preserve the integrity of the patent examination process that the Office's rules must organize. This approach, which gives the Office substantial leeway in the twilight zone of matters that one could rationally classify as procedure or substance, recognizes the Office's superior ability (relative to the courts) to frame rules that establish or preserve a fair and efficient examination process without running afoul of Congress's reserved power over substantive patent policy.

149. Id. at 112 .

150. Id. at 113 .

151. Id. at 115 .

152. Id. at 116 \& n.10; see also id. at 123 (O'Connor, J., concurring in the judgment) ("The regulation at issue here, which permits relation back of amendments to charges filed with the EEOC, is clearly such a procedural regulation. See, e.g., Fed. Rule Civ. Proc. 15 (establishing rules for amendments to pleadings and relation back as part of the Federal Rules of Civil Procedure). Thus, as the Court recognizes, see [Edelman], at 113-114, the EEOC was exercising authority explicitly delegated to it by Congress when it promulgated this rule."). 


\section{QUITTING THE BAD MODELS}

In addition to the REA, two other prominent federal statutes- the Administrative Procedure Act ${ }^{153}$ (APA) and the Rules of Decision Act ${ }^{154}$ (RDA)-give rise to frameworks for distinguishing procedural from substantive rules. Each may tempt a court confounded about how best to analyze a Patent Office rule attacked under § 2(b)(2)(A). Courts should resist these temptations, for both the APA and RDA sorting standards were developed to serve goals far removed from that of the Patent Act's aim of allocating responsibility for different facets of our long-divided patent power. Before discussing these inapposite frameworks in detail, however, I explain the idiosyncratic way the Patent Act invokes the APA's rulemaking requirements.

\section{A. The Patent Act's Reliance on Notice-and-Comment Rulemaking}

For at least a decade, it has been clear that "the PTO is an 'agency" subject to the APA's constraints." 155 And for several decades, the Office has followed the APA's notice-and-comment framework for promulgating binding rules of practice. 156 Commissioner Caspar Ooms, for example, speaking at an New York University Law School conference about administrative law in February 1947, described the Office's past and planned compliance with the strictures of notice-and-comment rulemaking under the APA. 157 More recently, in 1999, Congress codified that tradition. At the same time that it moved the longstanding grant of procedural regulatory power from $\S 6$ to $\S 2$ of the Act, ${ }^{158}$ Congress qualified the grant with an explicit reference to the part of the APA that establishes notice-and-comment rulemaking. The operative language in the Patent Act now states as follows:

153. 5 U.S.C. $\S \S 551-559,701-706$ (2006).

154. 28 U.S.C. $\S 1652(2006)$.

155. Dickinson v. Zurko, 527 U.S. 150, 154 (1999) (rejecting the Patent Office's contention that it was not bound by the standards of appellate review set forth in the APA).

156. See, e.g., Rules of Practice in Patent Cases: Different Inventions in One Application, 14 Fed. Reg. 5279, 5279 (Aug. 25, 1949) (proposing change to Rule 141, inviting comment, and setting deadline for comments of Sept. 30, 1949); 14 Fed. Reg. 6639, 6639 (Nov. 1, 1949) (finalizing change to Rule 141).

157. Casper W. Ooms, The United States Patent Office and the Administrative Procedure Act, 38 TRADEMARK REP. 149, 149 n.*, 153 (1948).

158. See supra note 8. 
The Office ... may establish regulations, not inconsistent with law, which-

(A) shall govern the conduct of proceedings in the Office; [and]

(B) shall be made in accordance with section 553 of title $5[.]^{159}$

In other words, when it wants to issue a rule to "govern the conduct of proceedings in the Office" that binds the public and appears among the formal rules of Patent Office practice in Title 37 of the Code of Federal Regulations, the Office must use notice-and-comment rulemaking to promulgate that rule.

Those familiar with the APA will appreciate that my construction of $\S 2$ (b)(2) of the Patent Act is, of necessity, purposive rather than literalistic. This is so because a literalistic reading of the provision would render the command to adhere to $\S 553$ of the APA an empty gesture, if not an outright absurdity. Consider: The Federal Circuit has construed $\S 2(\mathrm{~b})(2)(\mathrm{A})$ to confine the Patent Office to making procedural, not substantive, rules. ${ }^{160}$ Section 553 of the APA generally provides that, to promulgate a rule, an agency must give the public notice of the proposed rule and an opportunity to comment on the proposal. 161 Section 553 also expressly provides, however, that the requirements for notice-and-comment do not apply to certain types of rules-namely, "to interpretative rules, general statements of policy, or rules of agency organization, procedure, or practice."162 Given that $\S 553$ exempts agency procedural rules from notice-and-comment, and procedural rules are all that the Patent Office can promulgate, commanding the Office to comply with $\S 553$ does not literally require the use of notice-and-comment rulemaking. How, then, to break out of this logic trap?

The critical distinction that $\S 2(b)(2)$ of the Patent Act sets up is the one between more formal rules that bind members of the general public (i.e., patent applicants) and less formal rules, such as guidelines and policy statements, that do not. The Office frequently issues guidelines and other guidance documents that help inform the public of the Office's views on patent law, and, under $\S 553(\mathrm{~b})$ 's exceptions, the Office can do so without resort to notice-and-comment. For example, in the wake of the Supreme Court's recent landmark decision about the patent law doctrine of

159. 35 U.S.C. $\S 2(\mathrm{~b})(2)(\mathrm{A})-(\mathrm{B})(2006)$. For the provision that $\S 2(\mathrm{~b})(2)(\mathrm{B})$ codifies, see the Patent and Trademark Office Efficiency Act, Pub. L. No. 106-113, 113 Stat. 1501A-572, 1501A-573 (1999) (Title IV, Subtitle G, $\$ 4712$ of the Intellectual Property and Communications Omnibus Reform Act of 1999, included as Appendix I to an appropriations bill).

160. See supra note 9 .

161. 5 U.S.C. $\$ 553(\mathrm{~b})-(\mathrm{c})(2006)$.

162. 5 U.S.C. $\S 553(\mathrm{~b})$, ๆ 2 (A) (emphasis added). 
nonobviousness, ${ }^{163}$ KSR International Co. v. Teleflex Inc., ${ }^{164}$ the Patent Office published a policy document to "assist USPTO personnel to make a proper determination of obviousness under 35 U.S.C. [\$] 103 and to provide an appropriate supporting rationale."165 By publishing these guidelines, the Office also informed the public about the Office's perspective-admittedly nonbinding - on the scope of a core substantive patentability standard. To modify the formal rules of practice before the Patent Office, by contrast, the Office must use notice-and-comment rulemaking. Indeed, the Office proposed the rules challenged in the Tafas cases in just this manner. ${ }^{166}$

This construction of $\S 2$ finds support in related Patent Office provisions and in the legislative history of the 1999 insertion of the reference to $\S 553$. First, a portion of $\S 3$ of the Patent Act, which was also added in 1999, states that the Patent Office Director "shall consult with the Patent Public Advisory Committee ... on a regular basis on matters relating to the patent operations of the Office."167 The Patent Public Advisory Committee, created in 1999, is established in $\S 5$ of the Act, along with a parallel committee for the trademark side of the Office. ${ }^{168}$ Section 3 further states that the Director "shall consult with the respective Public Advisory Committee before...p proposing to change...p patent or trademark regulations which are subject to the requirement to provide notice and opportunity for public comment under section 553 of title 5."'169 This mandate presupposes,

163. 35 U.S.C. $\$ 103($ a).

164. 550 U.S. 398 (2007).

165. Examination Guidelines for Determining Obviousness Under 35 U.S.C. [\$] 103 in View of the Supreme Court Decision in KSR International Co. v. Teleflex Inc., 72 Fed. Reg. $57,526,57,526$ (Oct. 10, 2007).

166. See Changes to Practice for Continued Examination Filings, Patent Applications Containing Patentably Indistinct Claims, and Examination of Claims in Patent Applications, 72 Fed. Reg. 46,716 (Aug. 21, 2007). I have identified at least one other recent federal statute that appears to work much the same way as the Patent Act's reference to $\S 553$. Specifically, as part of the Congressional Accountability Act of 1995, Pub. L. No. 104-1, 109 Stat. 3 (codified at 2 U.S.C. $\$ \S 1301-1438$ (2006)), Congress created the Office of Compliance to administer the Act, 2 U.S.C. $\$ 1381$ (a) (2006). Congress also empowered the Office's Executive Director to "adopt rules governing the procedures of the Office," 2 U.S.C. § 1383(a), and at the same time provided that "[t]he Executive Director shall adopt [these procedural] rules ... in accordance with the principles and procedures set forth in section 553 of title 5," 2 U.S.C. $\S 1383($ b). The provision also lays out some changes from $\S 553$, relying on Congressional Record notice rather than Federal Register notice. Id. § 1383(b). Given that the phrase "in accordance with section 553 of title 5" appears eighty times in the United States Code (according to my search in Westlaw's USC database), it seems likely there are additional similar provisions.

167. 35 U.S.C. $§ 3(a)(2)(B)$.

168. 35 U.S.C. $\$ 5$.

169. 35 U.S.C. $§ 3(\mathrm{a})(2)(\mathrm{B})$ (emphasis added). 
then, that at least some patent regulations are subject to notice-and-comment rulemaking under $\S 553$ of the APA. Were one to construe $\S 2$ (b)(2) literalistically, dispensing with any need for notice-and-comment rulemaking in a puff of logic, one would also render $\S 3$ 's consultation command a nullity; it too, would refer to an empty set. Second, the legislative history of the 1999 enactment shows that, for at least three years preceding the final bill, both the House and Senate measures on this point referred not to rules "made in accordance with section 553," 170 but rather to rules "made after notice and opportunity for full participation by interested public and private parties," 171 i.c., notice-and-comment rulemaking. The legislative history materials do not record the reason for the surface shift to the text now codified in $\S 2(\mathrm{~b})(2)(\mathrm{B})$. Whatever the reason, the best reading of $\S 2$ is the one that harmonizes it with $\S 3 .{ }^{172}$ On this reading, the Patent Office can bind the public with the procedural rules it promulgates with the benefit of public comment after adequate notice, and not otherwise.

\section{B. The APA's Substance-Procedure Distinction}

Section 553 of the APA, as just noted, requires notice-and-comment for substantive rules but expressly excepts "rules of agency . . . procedure" from that mandate. ${ }^{173}$ This different treatment for substantive and procedural agency rules prompts challenges to agency rules alleged to be substantive but imposed without the requisite notice-and-comment. ${ }^{174}$ The courts adjudicating these challenges have thus developed a jurisprudence distinguishing procedural from substantive rules for purposes of $\S 553$. "The problem in this area, as in other areas of law, is that the distinction between procedure and substance is not always clear."175 Indeed, "[g]iven

170. 35 U.S.C. $\S 2(\mathrm{~b})(2)(\mathrm{B})$.

171. See H.R. 3460, 104th Cong. § 112 (1996); S. 1961, 104th Cong. § 112 (1996); H.R. 400, 105th Cong. $§ 112$ (1997); S. 507, 105th Cong. § 112 (1997); H.R. 1907, 106th Cong. $\S 612$ (as introduced by Rep. Coble, May 24, 1999).

172. "Courts have a 'duty to construe statutes, not isolated provisions." Graham Cnty. Soil \& Water Conservation Dist. v. United States, 130 S. C.t. 1396, 1404 (2010) (quoting Gustafson v. Alloyd Co., 513 U.S. 561, 568 (1995)). Indeed, "[s]tatutory construction ... is a holistic endeavor. A provision that may seem ambiguous in isolation is often clarified by the remainder of the statutory scheme... because only one of the permissible meanings produces a substantive effect that is compatible with the rest of the law." United Sav. Ass'n of Tex. v. Timbers of Inwood Forest Assoc., 484 U.S. 365, 371 (1988) (citations omitted).

173. 5 U.S.C. $\S 553(A)(2006)$.

174. See PIERCE, supra note 24, $\S 6.5$, at 353.

175. Jeffrey S. Lubbers \& Nancy G. Miller, The APA Procedural Rule Exemption: Looking for a Way to Clear the Air, 6 ADMIN. LJ. AM. U. 481, 484 (1992); see also GARY LAWSON, FEDERAL ADMINISTRATIVE LAW 297 (5th ed. 2009) (noting that "courts have had difficulty 
the inherent difficulty of the enterprise, the boundary between substantive rules and procedural rules is likely to remain murky."176

Murky or not, the $\S 553$ jurisprudence might appear at least superficially - to be a helpful resource for distinguishing procedural from substantive rules in the Patent Office context. "After all," one could reason, "Patent Act $\S 2(\mathrm{~b})(2)$ invokes $\S 553$ 's rulemaking requirements, albeit idiosyncratically." This surface connection may help explain the Federal Circuit's cautious flirtation, in the Tafas cases, with the D.C. Circuit's $§ 553$ jurisprudence. 177 Even as it "recognize[d] that the definitions of 'substance' and 'procedure' in the notice and comment rulemaking context may embody policy considerations that are not coextensive with the considerations at issue" in a $\S 2(\mathrm{~b})(2)$ challenge to a Patent Office rule, the Tafas II majority found "that these [ $\$ 553]$ cases are nevertheless helpful to the task of drawing a similar line between 'substance' and 'procedure' in [a $\S 2(\mathrm{~b})(2)]$ case." 178

But the $\S 553$ jurisprudence is not helpful for Patent Act cases, any more than salt water is helpful for quenching thirst. The APA distinguishes procedural from substantive rules for a purpose quite removed from that of the Patent Act; the tasks are similar in name alone. In the patent system, to hold that a rule is substantive is to put it beyond the Patent Office's reach, to conclude that it invades a matter of substantive patent policy that Congress has kept for itself. The purpose of the substance-procedure distinction in the Patent Act is to preserve the division of responsibility that Congress first put in place in 1836 and that Congress can adequately police itself. By contrast, in the typical agency context governed by the APAwhere Congress has empowered an agency to issue substantive as well as procedural rules - to hold that a rule is substantive is to require the agency to promulgate the rule only with the benefit of public comment after proper notice. The purpose of the substance-procedure distinction in the APA is to protect the general public's right to participate in an agency's formulation of the rules that regulate the public's primary conduct, ${ }^{179}$ and

distinguishing exempt rules of 'agency organization, procedure, or practice' (which are generally known collectively as 'procedural rules') from non-exempt substantive rules").

176. PIERCE, supra note $24, \S 6.5$, at 353.

177. See supra notes 88-91 and accompanying text.

178. Tafas II, 559 F.3d 1345, 1355 n.4 (Fed. Cir. 2009), vacated en banc, Tafas III, 328 Fed. App'x 658 (Fed. Cir. 2009) (appeal reinstated).

179. See supra note 23; see also Tracy Corell Hauser, The Administrative Procedure Act, Procedural Rule Exception to the Notice and Comment Requirement-A Survey of Cases, 5 ADMIN. L.J. 519 , 521 (1991) ("Congress enacted section 553 of the APA to make agencies more accountable to the public."). Indeed,

any interested party who so desires can participate in the ordinary rulemaking processes. ... At least at the level of responding to notice with comments about an 
courts are thus a vital check on agencies. In short, the arc of $\S 553$ bends toward substance, whereas the arc of $\S 2$ bends toward procedure.

The D.C. Circuit's $\S 553$ cases develop a method for using the substance-procedure distinction to protect public participation in agency development of substantive rules. This method, even if a bit "untidy," 180 is clear enough to rule itself out as an aid in deciding boundary disputes under Patent Act $\S 2(\mathrm{~b})(2)(B)$. The best way to dispel the temptation to rely on these cases when evaluating Patent Office rules is to discuss the cases in a bit of detail.

The foundational case in this line is Batterton v. Marshall, ${ }^{181}$ on which the D.C. Gircuit continues to rely. ${ }^{182}$ In Batterton, the state of Maryland challenged a new Department of Labor (DOL) method for calculating a locality's unemployment rate for purposes of disbursing federal job program funds. ${ }^{183}$ DOL adopted the new method without using noticeand-comment rulemaking. ${ }^{184}$ Maryland attacked the rule as procedurally defective, and DOL defended it as, among other things, within the exception to notice-and-comment for procedural rules. The rule was procedural, in that it provided the procedure for calculating an unemployment rate from observable variables. But it was also substantive, in that it gave the rate that dictated the size of a jurisdiction's federal payment. The court began by "focus[ing] on the underlying purposes of the procedural requirements at issue," stating that " $[t]$ he essential purpose of according $\S 553$ notice and comment opportunities is to reintroduce public participation and fairness to affected parties after governmental authority has been delegated to unrepresentative agencies." 185 In light of this protective purpose, "[e]xemptions should be recognized only where the need for public participation is overcome by good cause to suspend it, or

agency's proposed rule, there are no restrictions or limitations. Doing so requires parties only to keep abreast of an agency's proposed rules. And such comments need take no particular form. As a formal matter, then, rulemaking is an entirely open and inclusive process of decisionmaking.

Steven P. Croley, Theories of Regulation: Incorporating the Administrative Process, 98 Colum. L. REV. 1, 110 (1998) (footnotes omitted).

180. PIERCE, supra note $24, \S 6.5$, at 353 .

181. 648 F.2d 694 (D.C. Cir. 1980).

182. See, e.g., James V. Hurson Assoc. v. Glickman, 229 F.3d 277, 280 (D.C. Cir. 2000) (quoting Batterton's discussion of the "critical feature" that characterizes procedural rules for purposes of $\S 553$ ).

183. 648 F.2d at $696-99$.

184. Id. at 698 "This new method was never formally announced or published; [the Department of Labor] simply sent descriptive memoranda announcing the change to regional commissions and state unemployment security agencies.').

185. Id. at 703 . 
where the need is too small to warrant it . . ."186 Public participation is the default, and departures must be justified. Applying this exemption-wary approach to the question whether DOL's new method for determining the unemployment rate was a procedural rule under $\S 553$, the court acknowledged that " $[\mathrm{t}]$ he problem with applying the exception is that many merely internal agency practices affect parties outside the agency-often in significant ways." 187 It framed its test thusly:

A useful articulation of the exemption's critical feature is that it covers agency actions that do not themselves alter the rights or interests of parties, although it may alter the manner. in which the parties present themselves or their viewpoints to the agency.... The exemption cannot apply, however, where the agency action trenches on substantial private rights and interests. ${ }^{188}$

Pulling examples from prior cases, the court put "a freeze placed on the processing of applications for radio broadcast stations" and "a directive specifying that requisite audits be performed by nonagency accountants" on the procedural side of the line, and deemed it substantive "when drug producers are subject to new specifications for the kinds of clinical investigations deemed necessary" for new drug approval and "when motor carriers are subject to a new method for paying shippers."189 Finally, turning to the new DOL rule for measuring unemployment, the court concluded that it required public participation and was thus substantive:

Here, recipients of [federal] emergency job program monies are subject to a new method for determining the one undefined variable in the statutory fund allocation formula.... The critical question is whether the agency action jeopardizes the rights and interest of parties, for if it does, it must be subject to public comment prior to taking effect. As that is the case here, the exemption [for procedural rules] cannot apply. ${ }^{190}$

Maryland prevailed in its $\S 553$ challenge.

Three years later, in Lamoille Valley Railroad Co. v. Interstate Commerce Commission, ${ }^{191}$ the D.C. Circuit confronted a $§ 553$ challenge to an expedited schedule in a proceeding to review a railroad merger. ${ }^{192}$ This expedited schedule "gave competing railroads 60 days (instead of the usual 90) to file responsive applications," and the Interstate Commerce Commission (ICG)

186. Id. at 704 (footnote omitted).

187. Id. at 707 .

188. Id. at $707-08$.

189. Id.

190. Id. at 708 (footnote omitted).

191. 711 F.2d 295 (D.C. Cir. 1983).

192. Id. at 327 . 
issued it without using notice-and-comment rulemaking. ${ }^{193}$ The D.C. Circuit held that the schedule was within $\S 553$ 's exception for procedural rules. The court "put to one side cases like Batterton where a rule has definite substantive consequences but can arguably be called either 'procedural' or 'substantive,' and a court must decide which it is.'194 In this case, the court found it "hard to characterize the agency statement at issue ... as anything other than a rule of "procedure."' 195 Nevertheless, because "all procedural rules affect substantive rights to greater or lesser degree," further inquiry was required to determine "whether the substantive effect is sufficiently grave so that notice and comment are needed to safeguard the policies underlying the APA."196 The court tailored the inquiry to the scheduling context:

When a rule prescribes a timetable for asserting substantive rights, we think the proper question is whether the time allotted is so short as to foreclose effective opportunity to make one's case on the merits. This standard allows an agency ample discretion to structure its proceedings as it sees fit. However, when an agency abuses that discretion by creating extreme procedural hurdles that foreclose fair consideration of the underlying controversy, a court, by remanding for notice and comment, can ensure that the agency explores the substantive consequences of its "procedural" rule. ${ }^{197}$

Comparing the details of the standard and expedited schedules for the ICC railroad merger review under this foreclosure standard, the court concluded that the competitor railroads' opportunity to file responsive applications with the ICC had not been unduly abridged. Were it not for the Batteron default in favor of treating agency rules as matters for noticeand-comment (i.e., as substantive), one imagines the court would not have gone to such lengths to ensure that the plainly procedural rule at issue had only modest substantive effects. ${ }^{198}$

193. Id

194. Id. at 328 .

195. Id.

196. Id.

197. Id.; see also Nat'l Whistleblower Ctr. v. Nuclear Regulatory Comm'n, 208 F.3d 256, 263 (D.C. Cir. 2000) (upholding a Nuclear Regulatory Commission (NRC) "unavoidable and extreme circumstances" standard for granting leave to file late papers in the license renewal proceedings for the Calvert Cliffs nuclear facility and applying the Lamoille approach, on the ground that the NRC "standard did not foreclose participation by third parties seeking to intervene in the Calvert Cliffs proceeding").

198. Cf. FED. R. GIV. P. 4(m) (providing the time within which to serve a summons); 6(a) (providing rules for computing time under the Rules); 6(c)(1) (providing that, generally, a written motion must be served at least fourteen days before the noticed hearing date); 12(a) (providing times within which an answer must be filed, depending upon stated criteria). I could go on, but you get the point. If any of these time period Rules were challenged under 
In American Hospital Ass'n v. Bowen, ${ }^{199}$ a group of hospitals challenged a series of directives, transmittals, and guidelines that the Department of Health \& Human Services (HHS) issued in the wake of a 1982 change to the Medicare program. Congress enacted a new review program using peer review organizations (PROs) to "crack down on excessive reimbursements to hospitals for treatments of Medicare patients."200 Enacting only a "skeletal" framework, "Congress left much of the specifics of the hospital-PRO relationship to the inventiveness of HHS, empowering it to promulgate regulations governing PROs in order to implement the peer review program."201 HHS issued numerous rules, but without using notice and comment. An association representing 6,000 member hospitals sued to invalidate the rules. The D.C. Circuit began by affirming "that Congress intended the exceptions to $\S 553$ 's notice and comment requirements to be narrow ones": "In light of the obvious importance of these policy goals of maximum participation and full information, we have consistently declined to allow the exceptions itemized in $\S 553$ to swallow the APA's well-intentioned directive."202 Drawing on Batterton and other cases, the court explained that it "ha[d] generally sought to distinguish cases in which an agency is merely explicating Congress' desires from those cases in which the agency is adding substantive content of its own."203 It then described this approach to the exception for procedural rules as "inquiring more broadly whether the agency action," in addition to having a substantial impact on parties, "also encodes a substantive value judgment or puts a stamp of approval or disapproval on a given type of behavior."204 The court analyzed the series of directives at issue in the case in great detail, concluding that each of them was exempt from notice and comment. ${ }^{205}$

Batterton, Lamoille, and Bowen together established a framework for scrutinizing agency rules with an eye toward strongly protecting public participation in agency formulation of the rules designed to regulate people's primary conduct out in the world, and not merely secondary

the REA, they would surely pass muster under Hanna and Burlington Northern without the need to conduct anything like Lamoille's fair-consideration-foreclosure standard under the APA. And that is as it should be, for the REA and APA use a substance-procedure distinction for quite different purposes.

199. 834 F.2d 1037 (D.C. Cir. 1987).

200. Id. at 1041 .

201. Id. at 1043 .

202. Id. at 1044 .

203. Id. at 1045; see also id. at 1047 (quoting "critical feature" language from Batterton v. Marshall, 648 F.2d 694, 707 (D.C. Cir. 1980)).

204. Bowen, 834 F.2d at 1047 .

205. Id. at 1048-57. 
conduct in presenting a matter to the agency. Thus, for example, in $\mathcal{J} E M$ Broadcasting Co. v. FCC, ${ }^{206}$ the D.C. Circuit held that the FCC was not required to use notice and comment to promulgate a set of "stringent application processing rules designed to streamline the agency's review" of a large number applications for 689 newly allotted commercial frequency modulation (FM) channels. ${ }^{207}$ Citing Batterton, Lamoille, and Bowen, the court reasoned that "a license applicant's right to a free shot at amending its application is not so significant as to have required the FCC to conduct notice and comment rulemaking, particularly in light of the Commission's weighty efficiency interests." 208 Moreover, the new rules "did not change the substantive standards by which the FCC evaluates license applications, e.g., financial qualifications, proposed programming, and transmitter location."209 By contrast, in Chamber of Commerce v. United States Department of Labor, ${ }^{210}$ the D.C. Circuit invalidated an Occupational Safety and Health Administration (OSHA) directive that placed "12,500 relatively dangerous workplaces" on a new "primary inspection list," with a guaranteed "comprehensive inspection before the end of 1999," at the same time the agency promised to remove a workplace from the list - thereby "reduc[ing] by 70 to 90 percent the probability that it [would] be inspected"-if "it adopt[ed] a comprehensive safety and health program designed to meet standards that in some respects exceed[ed] those required" by statute. ${ }^{211}$ OSHA issued the directive without notice and comment, and the court held this defect invalidated the rule because the rule was substantive. Drawing explicitly, again, on Batterton and Bowen, as well as $7 E M$, the court reasoned that " $[t]$ he Directive is intended to, and no doubt will, affect the safety practices of thousands of employers. The value of ensuring that the OSHA is well-informed and responsive to public comments before it adopts a

206. JEM, 22 F.3d 320 (D.C. Cir. 1994).

207. Id. at 322. The Federal Communications Commission (FCC) had dismissed JEM's application for a station, and would not permit JEM to refile, when it determined that JEM's application provided conflicting geographic coordinates for its proposed transmitter site in violation of the rules. Id. at 323 .

208. Id. at 327

209. Id. Similarly, in James V. Hurson Associates v. Glickman, 229 F.3d 277 (D.C. Cir. 2000 ), the court upheld against a $\S 553$ attack a United States Department of Agriculture rule canceling an in-person-meeting method it had used for granting quicker approval of a producer's proposed food safety label. Quoting liberally from $J E M$, the court held that "[t]he agency's abolition of face-to-face [meetings] did not alter the substantive criteria by which it would approve or deny proposed labels; it simply changed the procedures it would follow in applying those substantive standards." Id. at 280-81.

210. 174 F.3d 206 (D.C. Cir. 1999).

211. Id. at 208. 
policy is therefore considerable." 212

Batterton and its progeny do yeoman service in protecting the public's right to participate when the typical federal agency writes a substantive rule, the very goal that $\S 553$ sets in distinguishing substantive from procedural rules for notice-and-comment treatment. But these cases have nothing to teach us about the scope of the Patent Office's rulemaking power, which binds the public only when deployed with notice-andcomment and which must avoid substantive patent policy even with the most punctilious notice-and-comment. The enabling act approach is a far better fit for the Patent Act, because it is tailored closely to the goal of enabling the Patent Office to make rules reasonably calculated to establish or preserve a fair and effective examination process for applicants, while at the same time prohibiting any glaring invasions of Congress's substantive patent policy turf.

\section{The Rules of Decision Act's Substance-Procedure Distinction}

The Rules of Decision Act (RDA) provides that " $[\mathrm{t}]$ he laws of the several states ... shall be regarded as rules of decision in civil actions in the courts of the United States."213 The text is identical in substance to its predecessor in the Judiciary Act of $1789,{ }^{214}$ even as so much else around it has changed. In Erie Railroad v. Tompkins, ${ }^{215}$ a diversity case, the Supreme Court held that the RDA requires federal courts to apply not only state positive law, but also state decisional law. ${ }^{216}$ Federal courts also, at the same time, apply federal procedural law, even in diversity cases. Indeed, "[ $t]$ he rules that were developed under the authority of the [REA] were adopted by the Supreme Court on December 20, 1937, and took effect on September 1, 1938, less than five months after Erie was handed down."217

The RDA thus sets up its own substance-procedure distinction: "Under the Erie doctrine, federal courts sitting in diversity apply state substantive

212. Id. at 212 .

213. 28 U.S.C. $\S 1652$ (2006). The Rule of Decision Act's (RDA's) full text is quoted supra, note 31 .

214. Act of Sept. 24, 1789, ch. 20, §34, 1 Stat. 73, 92 ("And be it further enacted, That the laws of the several states, except where the constitution, treaties or statutes of the United States shall otherwise require or provide, shall be regarded as rules of decision in trials at common law in the courts of the United States in cases where they apply.")

215. 304 U.S. 64 (1938).

216. Id. at 78. The same is true when state law supplies the rule of decision for a claim as to which a federal court has supplemental jurisdiction under 28 U.S.C. $\$ 1367$. See Felder v. Casey, 487 U.S. 131, 151 (1988).

217. Houben v. Telular Corp., 309 F.3d 1028, 1033 (7th Cir. 2002). 
law and federal procedural law."218 How does this distinction play out, and might it help us work out an approach to determining the scope of the Patent Office's regulatory power? The breadth and depth of the Erie jurisprudence and commentary is staggering. ${ }^{219}$ Even a modest exploration of the materials would take us far beyond the scope of this Article. But a small number of its settled principles suffice to show that Erie's choice-oflaw framework offers no help at all in sorting procedural from substantive Patent Office rules under $\S 2(\mathrm{~b})$ of the Patent Act.

In Erie itself, the operative question was the scope of a railroad's duty to a person who was injured by a passing train while walking along the railroad's right of way. ${ }^{220}$ As the Seventh Circuit recently observed, this was an "obvious rule [] of substance," 221 and the Supreme Court held that Pennsylvania state tort decisions supplied the rule of decision in the case. ${ }^{222}$ In Hanna, as I described earlier, ${ }^{223}$ the operative question was the manner of serving process. The Massachusetts statute that would have applied in state court conflicted with Federal Rule of Civil Procedure 4, with which the diversity plaintiff had fully complied.224 The Supreme Court opined that " $[w]$ hen a situation is covered by one of the Federal Rules, the question facing the court is a far cry from the typical, relatively unguided Erie choice."225 Where there is a Federal Rule on point, "the court has been instructed to apply the Federal Rule, and can refuse to do so only if the Advisory Committee, th[e Supreme] Court, and Congress erred in their prima facie judgment that the Rule in question transgresses neither the terms of the Enabling Act nor constitutional restrictions."226 These polar

218. Gasperini v. Ctr. for Humanities, Inc., 518 U.S. 415, 427 (1996). For a recent application of the Erie doctrine in the circuit courts, see Kohlrautz v. Oilmen Participation Corp., 441 F.3d 827 (9th Cir. 2006).

219. For an excellent start, the interested reader should consult Adam N. Steinman, What is the Erie Doctrine? (And What Does It Mean for the Contemporary Politics of Judicial Federalism?), 84 NOTRE DAME L. REV. 245 (2008).

220. Erie R.R. v. Tompkins, 304 U.S. 64, 69-70 (1938).

221. Houben, 309 F.3d at 1033.

222. Erie, 304 U.S. at 78-79.

223. See supra notes $115-21$ and accompanying text.

224. Hanna v. Plumer, 380 U.S. 460, 461-62 (1965).

225. Id. at 471; see also id. at 473 ("Erie and its offspring cast no doubt on the longrecognized power of Congress to prescribe housekeeping rules for federal courts even though some of those rules will inevitably differ from comparable state rules."); Erie, 304 U.S. at 92 (Reed, J., concurring) ("The line between procedural and substantive law is hazy but no one doubts federal power over procedure."). This collision vel non between federal rule and state law is the question that sharply divided the Supreme Court in the Shady Grove case. See supra note 122.

226. Hanna, 380 U.S. at 471 ; see also Burlington N. R.R. v. Woods, 480 U.S. 1, 4-5 (1987) ("In Hanna v. Plumer, we set forth the appropriate test for resolving conflicts between 
cases are relatively straightforward.

Middle cases have presented a deeper challenge. "The Court's first effort to grapple with the middle ground came in Guaranty Trust Co. $v$. York, [227] in which it had to decide whether a state statute of limitations barred a claim brought for breach of trust."'228 Applying what it would later call "'[o]utcome-determination' analysis," 229 the York Court concluded that the state limitations statute applied: "The question is . . does it significantly affect the result of a litigation for a federal court to disregard a law of a State that would be controlling in an action upon the same claim by the same parties in a State court?"'230

The York approach did not last, however, for it "swept too much under state law."231 Hanna adjusted York by refracting it back through Erie's policy lens. "The 'outcome-determination' test therefore cannot be read without reference to the twin aims of the Erie rule: discouragement of forumshopping and avoidance of inequitable administration of the laws."232 This Hanna gloss on York established the anti-forum-shopping approach that the Supreme Court continues to follow in such "unguided Erie choice" cases. ${ }^{233}$ Each of these moves - from Erie to York to Hanna and beyond-is, in its

state law and the Federal Rules. The initial step is to determine whether, when fairly construed, the scope of Federal Rule 38 is sufficiently broad to cause a direct collision with the state law or, implicitly, to control the issue before the court, thereby leaving no room for the operation of that law. The Rule must then be applied if it represents a valid exercise of Congress' rulemaking authority, which originates in the Constitution and has been bestowed on this Court by the Rules Enabling Act." (internal quotations and citations omitted)).

227. 326 U.S. 99 (1945).

228. Houben v. Telular Corp., 309 F.3d 1028, 1033 (7th Cir. 2002).

229. Hanna, 380 U.S. at 466.

230. 326 U.S. at 109 .

231. Houben, 309 F.3d at 1034; see also Ely, supra note 20, at 709 ("But although it held sway for quite a time, York's outcome determination test seemed overbroad.").

232. Hanna, 380 U.S. at 468.

233. See, e.g., Gasperini v. Ctr. for Humanities, Inc., 518 U.S. 415, 427-28 (1996); Chambers v. NASCO, Inc., 501 U.S. 32, 52-53 (1991); Stewart Org., Inc. v. Ricoh Corp., 487 U.S. 22, 27 n.6 (1988); Walker v. Armco Steel Corp., 446 U.S. 740, 752-53 (1980); see also AXA Corporate Solutions v. Underwriters Reins. Corp., 347 F.3d 272, 276 (7th Cir. 2003) ("[T] he distinction between 'substantive' issues and 'procedural' issues in cases applying the doctrine first announced in Erie ... should be understood as shorthand for a more complex inquiry. That inquiry requires courts to refer to the twin aims of the Erie doctrine, which are to discourage forum-shopping and to avoid the inequitable administration of laws." (citation omitted)); Steinman, supra note 219, at 265 ("For the last forty years (since Hanna), the Supreme Court has consistently stated that such choices must be made with reference to the twin aims of the Enie rule: discouragement of forum-shopping and avoidance of inequitable administration of the laws. If federal judicial lawmaking would disserve these two policies, then the federal court must follow state law." (internal quotation marks and footnote omitted)). 
way, the stuff of nuance and filigree, subject to heartfelt debate among judges and scholars. But the broad outline recounted here, at least, is uncontroversial.

The RDA, and the Erie jurisprudence implementing it, focus on preventing forum shopping between the state and federal courts, and the frictions such forum shopping can produce. This policy response has no bearing on the Patent Act context, for the simple reason that obtaining a U.S. patent offers no prospect of forum shopping. There is one, and only one, forum in which to obtain a U.S. patent as a matter of right, and that forum is the U.S. Patent \& Trademark Office. No amount of judicial parsing of substantive from procedural Patent Office rules under $\S 2$ (b) can change this fact.

\section{CONCLUSION}

Two years after Erie and the first Federal Rules of Civil Procedure, Professor Thomas Green quipped that " $\mathrm{t}]$ he answer to the question, 'What is procedure?' depends upon the answer to another question, 'Why do you want to know?"'234 This is functionalism, not fatalism. And a functional approach to the patent law version of the question-what is a procedural rule for purposes of $\S 2(\mathrm{~b})(2)(\mathrm{A})$ of the Patent Act? - takes cognizance of the basic allocation of substantive and procedural roles that Congress made when it split the patent power in 1790 . The primary rigors of congressional oversight permit the courts to serve as a secondary backstop, affording the Office substantial freedom to treat as procedural the matters it finds in the twilight zone between clear procedure and clear substance. A court should thus uphold a Patent Office rule against a $\S 2(\mathrm{~b})(2)(\mathrm{A})$ attack where the Office can explain how the rule reasonably helps the Office establish or preserve a fair and effective examination process for applicants, notwithstanding an incidental effect on applicants' substantive patent rights.

234. Green, supra note 1 , at 483. 
*** 